\title{
Determinants of Sovereign Credit Ratings in Emerging Markets
}

\author{
Oluyomi A. Osobajo ${ }^{1}$ \& Adeola E. Akintunde ${ }^{1}$ \\ ${ }^{1}$ Aberdeen Business School, Robert Gordon University, Aberdeen, AB10 7QE, Scotland \\ Correspondence: Oluyomi A. Osobajo, Aberdeen Business School, Robert Gordon University, Aberdeen, AB10 \\ $7 \mathrm{QE}$, Scotland.
}

Received: March 6, 2019

doi:10.5539/ibr.v12n5p142
Accepted: April 18, $2019 \quad$ Online Published: April 26, 2019

URL: https://doi.org/10.5539/ibr.v12n5p142

\begin{abstract}
This study critically investigates the determinants of sovereign credit ratings in emerging markets, during 2001 to 2015. This was conducted in 20 emerging markets, using S\&P and Moody ratings. Linear framework econometric approach with the use of pooled Ordinary Least Square regression method was adopted in the study. The explanatory power of the estimated models has a good performance across both rating agencies. The study reveals the importance of five macroeconomic variables in determining the sovereign credit rating of emerging markets. These variables are: gross domestic product per capital, inflation, government debt, reserves, and external debt. Also, world governance indicators, a proxy for qualitative/political variables, were found to be an essential determinant of rating.
\end{abstract}

Keywords: sovereign credit rating, credit rating, credit rating agency, emerging market

\section{Introduction}

Sovereign credit rating (SCR) is considered imperative in assessing the value and worth of a nation's economy, which invariably has an effect on other borrowers of the same nationality (Reisen, Von Maltzan, \& Larraín, 1998). It is of immerse importance to economic agents, fund managers and lenders for decision making (Afonso et al., 2011) and attracts and promotes foreign direct investment (Al-sakka \& Gwilym, 2009). This is because it measures the ability and willingness of a national government or country to repay its debt in a timely manner (Al-sakka and Gwilym, 2012; Erdem \& Varli, 2014). Reinhart and Rogoff (2004) alleged that SCR aids the flow of capital to emerging markets. This has given rise to a tremendous increase in the number of rated emerging markets (Cantor et al., 2008). Kim and Wu (2008) added that SCR is the most important factor in developing the domestic financial sector of emerging markets and also to fascinate international capital. Likewise, Al-sakka and Gwilym (2009) claimed that SCR promotes cross-border investment by revealing the financial transparency of the market economies. Erb et al. (2000) added that SCR determines the movement of sovereign bonds price, while Dittmar and Yuan (2008) concluded that sovereign bonds provide a good flow of information that promotes corporate bonds market. This in effect, increases liquidity in the emerging markets.

Furthermore, Banerjee (2006) asserted that there has been increasing investment opportunities to global investors in emerging markets. This has been partly attributed to market globalisation and financial integration, which have tremendously increased the demand of SCR in recent years (Al-sakka \& Gwilym, 2009; Montes et al., 2016). Despite the foregoing, a number of emerging markets had faced debt crises in recent years (Dailami et al., 2003). This could be attributed to investors' reliance on sovereign rating when investing in emerging markets due to lack of information. In addition, Biglaiser et al (2008) asserted that the high level of risk associated with emerging markets was a contributing factor. The sovereign risk was the major concern during the 2010/2011 global financial markets development. The International Monetary Fund (IMF) argues that sovereign default was the most important risk facing the global economy which was stated in the Global Financial Stability Report in 2010. This suggests that the significance and role of sovereign credit rating cannot be undermined in the development of the economy. Hence, it is crucial to have an assessment of the factors that determine the SCR.

Even though the determinants of SCR have obtained meritorious attention from academics (for instance, Cantor and Packer, 1996; Alexe et al., 2003; Afonso, 2003; Rowland, 2004; Bissoondoyal-Bheenick, 2005; Altenkirch, 2005; Bennell et al. 2006; Afonso et al., 2007; Hill et al., 2010; Ozturk, 2014). Yet, the article that exclusively explores that of the emerging market is still limited (Montes et al., 2016). 


\section{Literature Review}

\subsection{What is Credit Rating?}

The term credit rating has been defined by scholars, regulatory bodies and rating agencies from different perspectives. According to IMF (2010, p. 88), credit rating had been defined as "a measure of the relative risk that an entity or transaction will fail to meet its financial commitments, such as interest payments and repayment of principal, on a timely basis". Likewise, Gonis et al. (2012) stated that credit rating provides an independent appraisal of an entity capacity to service its debts obligation in a timely manner. These definitions suggest that credit rating assesses the probability of default of an entity and also indicate the importance of time in the credit rating process. Colquitt (2007) asserted that credit rating act as a road map in the management of credit risk by appraising the credit worthiness and estimating the probability of default of an entity according to rating categories. Furthermore, Kronwald (2009) asserted that credit rating is an appraisal of the credit risk of a potential debtor, forecasting their ability of debt payment, and predicting the default probability of the debtor. Al-sakka and Gwilym (2009) added that credit rating is an analysis of the credit risks associated with an entity, while Shen et al. (2012) concluded that all the risk factors that the CRAs perceived, are integrated into credit ratings. This suggests that credit rating examines only the probability of loss as a result of an entity failure. Hence, credit rating does not incorporate other types of risk such as market risk or liquidity risk (De Haan \& Amtenbrink, 2011.).

However, from the perspective of the CRAs, credit rating is more or less an opinion. Standard \& Poor's Financial Services (2014, p. 4), defined credit rating as "a forward-looking opinion about the creditworthiness of an obligor with respect to a specific financial obligation, a specific class of financial obligations, or a specific financial program" '. Likewise, Moody's (2006, p. 1) defined "credit ratings are opinions of the credit quality of individual obligations or of an issuer's general creditworthiness", while Fitch Ratings' (2016, p.1) asserted that credit ratings "provide an opinion on the relative ability of an entity to meet financial commitments, such as interest, preferred dividends, repayment of principal, insurance claims or counterparty obligations". These views suggest that the CRAs definitions of credit rating are opinions and/or estimations about a firm's likelihood of default.

\subsection{Sovereign Credit Rating ( $S C R$ )}

Reinhart (2002) defined SCR as a measure of the default risk of a country. Likewise, Alexe (2003) referred to SCR as a "country risk". He asserted that SCR measures the risk associated with a country's probability of default. He argued further that the default of a country can be analysed from two perspectives. Firstly, the country's capacity to service its debt. This means the ability of a country to meet its debt obligation as a result of the country's solvency. Secondly, the cost-benefit approach which evaluates the default of a country has a deliberate choice i.e. the unwillingness of the country to fulfill its commitments. The above argument is consistent with Bissoondoyal-Bheenick (2005), Afonso et al. (2011), and Montes et al. (2016) assertion that "sovereign credit ratings are condensed assessment of a government's ability and willingness to repay its public debt on time". Also, Al-sakka and Gwilym, (2012) stated that sovereign credit rating is the risk assessments allocated to the central government's obligations by credit rating agencies. Likewise, Erdem and Varli (2014) asserted that sovereign credit rating is an evaluation assigned by rating agencies about the economic and financial obligations of a specific country. These views and opinions of scholars suggest that sovereign credit rating measures the risk associated with a country and it also estimates the likelihood of default of such country.

\subsection{Overview of Credit Rating Agencies}

The first credit rating was published by John Moody in 1909, which was on railroad bond ratings in the US (White 2010). This was followed by Poor's publishing company in 1916, while standard statistics company emerge in 1922. In 1924, Fitch publishing company was also established. However, Poor's publishing company and standard statistics company merged in 1941 and became standard and poor (S\&P). The existence and importance of this CRAs has been the reliance on credit rating as a measure of credit risk. White (2010) asserted that the basic problem in finance of how to determine the creditworthiness of a potential borrower has been the major reason for the existence of the CRAs. However, increase in the international financial markets has expanded the establishment of CRAs to Europe, Japan, other developed countries and emerging markets. Pavkovic and Vedris (2011) stated that CRAs were over 150 in 1999 but in 2009, they were reduced to 73. White (2010) added that three major CRAs (i.e. S\&P, Moody's, and Fitch) share roughly 95\% of the global market in 2003 with S\&P's and Moody's having approximately 40\% each and Fitch around 15\%. Host et al. (2012) added that as at 2003 in the USA market, only these three rating agencies were approved by National Recognized Statistical Ratings Organization (NRSRO) to assign credit rating. However, in 2011, NRSRO approved 10 CRAs but with the major three, operating globally in all sectors of the economy while others focus on specific sectors. 


\subsection{Determinants of $S C R$}

The determinants of SCR have aroused the attention of researchers in recent times, as several studies have tried to identify and model these factors. Scholars have examined these factors from different viewpoint.

From the perspective of those that argued that SCRs analysis should be restricted to only economic variables, Cantor and Packer (1996) carried out the first investigation on the significant of macroeconomic variables on the SCRs, which were given by S\&P and Moody's. They employed 8 variables which are: GDP growth, inflation, level of economic development, fiscal balance, per capita income, external debt, external balance, and a country's default history. The study was conducted in 49 countries, which consisted of both developed and developing countries in the year 1995. They concluded that six variables (i.e. GDP growth, default history, per capita income, economic development level, inflation and external debt) are relevant to the determinant of SCR. However, they did not find any systemic relationship between either external balance (current deficit) or fiscal balance and SCR. Also, Afonso (2003) examines the factors that determine sovereign debt ratings of S\&P's and Moody's 2001. Like Cantor and Packer (1996), this study examined 81 countries of which was both developed and developing countries. His study reported that SCRs can be explained by six major macroeconomic factors. These factors include GDP per capital, real growth rate, external debt to export ratio, level of economic development, default history, and inflation rate. Furthermore, Rowland (2004), used the same econometric framework with Cantor and Packer (1996). The study was conducted in 49 developing countries with the least rating of B-. He discovered that the growth rate of the economy, external debt ratios, GDP per capita, inflation rate, international reserves level, and debt service ratios are the essential macroeconomic factors that determine SCRs. Archer et al. (2007) conducted their investigation in 50 developing countries during the period of 1987 and 2003. The study reported that economic variables such as inflation rate, default history, GDP growth rate and commitment to trade are the major factors that affect sovereign ratings.

From the perspective of those that argued that there should be inclusion of political variables, Afonso et al. (2011) in their attempt to differentiate between the long run and short run effect of macroeconomic and fiscal variables on rating, they discovered the importance of qualitative variables. They argued that government effectiveness has long run impact on SCRs. Likewise, Biglaiser and Staats (2012) exploit 36 developing countries during the period of 1996 and 2006. They added new political and institutional variables such as society's obedience to the rule of law, the protection of property rights, and the presence of strong and independent judicial system in order to extend the study. Their result suggests that political variables play a crucial role in influencing and determining SCRs. Ozturk (2014) employed both macroeconomic variables and six governance indicators in an attempt to analyse SCRs with the use of ordered response models. The six governance indicators are Government Effectiveness, Control of Corruption, Political Stability and No Violence, Regulatory Quality, Voice and Accountability, and Rule of Law. In addition, Montes et al. (2016) analysed the determinants of SCRs from the three major rating agencies. The study examined 40 developing countries during the period of 1994 and 2013. They extended the study by adding new institutional, economic and governance variables such as corruption, democracy, financial openness, inflation targeting etc. Their study reveals that SCRs can be determined by macroeconomic factors such as inflation rate, GDP growth rate, foreign reserves, per capita income, government budget balance, external debt, unemployment rate. Also, the study argued that less corruption, democracy, and law and order are essential variables in improving SCRs.

The arguments in the previous studies suggest that economic variables are very important in determining SCRs while the inclusion of political variable is the issue of contest. The CRAs asserted that they put into consideration both the quantitative factors (i.e. macroeconomics variables) and qualitative factors (political factors) in determining their ratings (Archer et al., 2007; IMF, 2010). However, the difficulty in measuring political variables might be one of the problems (Archer et al., 2007). This is because political variables are not easily quantified compared to economic variables. This study critically investigates the factors behind SCRs of the emerging markets, using the three major CRAs ratings.

\subsubsection{GDP Growth}

In analysing the relationship between rating and GDP growth, Cantor and Packer (1996) used the rating assigned by Moody and S\&P in 1995. They argued that there is a positive relationship, as GDP growth was found to be positively significant in both CRAs. However, Rowland (2004) using the same CRAs ratings asserted that GDP growth has significant effect on S\&P's ratings whereas it was found insignificant on Moody's ratings. Similarly, Archer et al. (2007) argued that GDP growth is highly significant with a positive sign for the three major rating agencies (i.e. Moody, Fitch, and S\&P). This is consistent with Afonso et.al (2007) and Montes et al. (2016) findings, that GDP growth is significant for the three CRAs. However, Erdem and Varli (2014) asserted that no 
relationship was found between GDP growth and S\&P SCRs.

\subsubsection{GDP Per Capita}

Cantor and Packer (1996) stated that GDP per capita is statistically significant with a positive sign for both Moody's and S\&P's ratings. This is also consistent with Afonso (2003), and Rowland (2004) assertions. Likewise, using only S\&P ratings, Alex (2003), Erdem and Varli (2014) reported that GDP per capita is statistically significant with the expected sign. Also, using the three major rating agencies, Archer et al. (2007) reported that only S\&P ratings were statistically significant, while Moody and Fitch were not. However, Afonso et.al (2007), Montes et al. (2016), argued that GDP per capital was significant and positive in all the three CRAs. Afonso et al. (2011) added that GDP per capital is only significant in the short run but has no effect in the long run for the three CRAs. Furthermore, Biglaiser and Staats (2012) stated that GDP per capital was not significant in any of the CRAs ratings.

\subsubsection{Inflation}

Lower inflation is constantly related to higher ratings (Cantor \& Packer, 1996). Their study reported that inflation is statistically significant with rating and it has a negative sign. Rowland (2004) argued that even though inflation was with the expected sign, it was found insignificant in Moody's ratings but negatively significant in S\&P ratings. However, Altenkirch (2005) claimed that inflation was negative and significant in Moody's ratings. Furthermore, Afonso et.al (2007) argued that inflation has negative impact on the ratings. Their study reported that inflation is significant across the three major CRAs. This is consistent with Archer et al. (2007), Montes et al. (2016) findings. In contrary to the previous findings, Biglaiser and Staats (2012) stated that inflation has a positive impact on rating. Their study reported that inflation was found significant with a positive sign. This implies that the higher the inflation, the higher the rating. Furthermore, Erdem and Varli (2014), affirms the negative significant of inflation on S\&P's rating.

\subsubsection{External Debt}

In analysing the relationship between rating and external debt, Cantor and Packer (1996) asserted that lower external debt is correlated with higher ratings. Their study reveals that external debt was found to be negatively significant. This is also consistent with Afonso (2003) and Rowland (2004) assertions. However, Archer et al. (2007) using the three CRAs claimed that external debt was found to be negative and significant only in Fitch's rating. Whereas, Afonso et.al (2007), Biglaiser and Staats (2012), Montes et al. (2016) argued that external debt seems to be an essential determinant of ratings. Hence, a lower external debt enhances and improves ratings. This was found significant in all the three CRAs with the expected negative impact. Afonso et.al (2011), added that external debt affects rating both on the short run and long run.

\subsubsection{Economic Development Level}

Cantor and Packer (1996) stated that high level of economic development is associated with high rating. They added that the level of economic development has the likelihood of increasing a country's rating. Thus, it has a positive impact on rating and was found to be statistically significant. This is also consistent with Afonso (2003) findings. Their study reported that level of economic development is positive and highly significant with Moody's and S\&P's ratings. Also, Zheng (2012) in an attempt to analyse the differences between S\&P's rating and Dagong (Chinese credit rating agency) rating, reported the positive significant of economic development level in influencing rating.

\subsubsection{Default History}

This variable places a limitation on a country's rating and thus has a negative effect on rating (Cantor and Packer, 1996). Using the ratings of Moody and S\&P, Cantor and Packer (1996) and Afonso (2003) asserted that default history is negatively significant with ratings. On the contrary, Rowland (2004) argued that there is no relationship between default history and rating. His study reported that default history is statistically insignificant to rating. Furthermore, Archer et al. (2007) stated that the most important variable in determining rating is default history. He added that not defaulting is the most obvious policy influence, a country can make in order to keep its rating up. Therefore, defaulting reduces rating and vice versa. Their study revealed that default history is highly significant and negative, using the three major CRAs ratings. Afonso et al. (2007), Hill et al. (2010) affirms the significant of default history for the three major CRAs ratings.

\subsubsection{Current Account Balance}

Cantor and Packer (1996) asserted that there is no relationship between current account balance and rating. Also, Erdem and Varli (2014) using only S\&P's ratings, affirms that current account is insignificant and no impact on 
rating. However, Mulder (2000), Eliasson (2002), Altenkirch (2005) and Afonso et al. (2007) reported that current account balance has a negative impact on rating and was found to be significant. This implies that the higher the current account balance, the lower the rating and vice versa. In addition, Archer et al. (2007) findings reveal that there is no relationship between either Fitch's or Moody's rating or current account balance. Whereas, it was found significant in S\&P's rating (moving average) with a negative impact. Furthermore, Afonso et al. (2011) affirm the negative significant of current account balance on the three CRAs.

\subsubsection{Level of Unemployment}

Afonso et al. (2007) argued that there is no clear relationship between rating and unemployment. Their study revealed that the average level of unemployment was negatively significant with Moody's rating, whereas, it was positively significant with S\&P's rating from the average short-run deviation. This is consistent with Afonso et.al (2011) assertion, in differentiating between the short and long run effect of unemployment on rating. However, Erdem and Varli (2014) using only S\&P's ratings, argued that there is no relationship between unemployment level and rating. Their study revealed that unemployment level is insignificant to rating. Montes et al. (2016) added that though unemployment level is insignificant in some of their models, its coefficient depicts that low level of unemployment can enhance SCRs.

\subsubsection{Foreign Reserve}

Rowland (2004), Altenkirch (2005), Afonso (2007) claimed that foreign reserve is significant and has a positive impact on rating. However, Afonso et.al (2011) argued that foreign reserve is positively significant with Moody's rating at the short run whereas it affects Fitch's and S\&P's rating at the long run. Also, Erdem and Varli (2014) using only S\&P's ratings affirms that foreign reserve is significant and positive. Likewise, Montes et al. (2016) stated that foreign reserve has a positive impact on three major CRAs ratings. Hence, it was found to be significant.

\subsubsection{Political Variables}

Several political variables have been explored in analysing the relationship between rating and qualitative variables. Altenkirch (2005) used political right has a proxy for democracy. He argued that it is significant and positive. Also, Afonso et al. (2007 and 2011) reported the positive significant of government effectiveness. Archer et al. (2007), added that though executive party tenure was significant, it was positive in Moody's and Fitch ratings while it was negative for S\&P rating. Likewise, Biglaiser and Staats (2012) stated that chief executive tenure and honeymoon are negatively significant for all Fitch models while S\&P and Moody are not generally significant. However, democracy was reported insignificant (Archer et al., 2007; Biglaiser \& Staats, 2012). In addition, Erdem and Varli (2014) used the average of six governance indicators (such as control of corruption, government effectiveness, political stability and absence of violence, regulatory quality, rule of law, and voice and accountability) and reported that it was significant and positive. Furthermore, Montes et al. (2016) argued that institutional dimension (i.e. law and order, and democratic) were negatively significant. They added that increase in these variables can lead to economic stability, which as a result can improve SCRs of a country.

\section{Methodology}

This study employs a longitudinal study because it has the capacity to study change and development. It is also useful for comparison as there has been a drastic increase in the demand of SCR by the emerging markets. Therefore, the study constitutes a sample of 20 emerging markets, during the period of 2001 to 2015 as presented in figure 1. The time horizon was chosen to reflect the most recent years which has not been included in the existing literature. These countries were selected based on some formed lists of economies in the categories of emerging markets. These lists include Bloomberg list, IMF list, MSCI list, FTSE list, Standard \& Poor's list, Emerging Market bond index, and Dow Jones list. The twenty countries selected appeared in all the seven lists and were chosen across the market classification (i.e. region).

Brazil, Chile, China, Colombia, Egypt, Hungary, India, Indonesia, Malaysia, Mexico, Morocco, Peru, Philippines, Poland, Qatar, Romanian, Russian, South Africa, Thailand, Turkey.

\section{Figure 1. List of selected countries}

\subsection{Explained Variable}

The emerging markets SCRs serve as the explained variable whose variation is being examined. So, the study employs the ratings assigned by Moody, and S\&P. This enables comparison among the CRAs. Ratings are conveyed in alphabetical letters and/or figures which range from AAA/Aaa to D. Different scales have been used in converting ratings into numerical data in the previous literature. This ranges from 1-21, 1-17 and 1-9. 
However, the study uses the rating scale of 1 to 21 where 1 is the highest probability of default and 21 is the lowest probability of default as shown in table 1 . This help to capture the variation between each rating. These ratings are obtained from the CRAs websites.

Table 1. Long-Term Rating Scale of the Three CRAs

\begin{tabular}{|c|c|c|c|c|}
\hline Interpretation & Fitch and S\&P & Moody's & \begin{tabular}{|c|}
$\begin{array}{c}\text { Classification } \\
\text { of Grade }\end{array}$ \\
\end{tabular} & Rating Scale \\
\hline Highest quality & AAA & Aaа & \multirow{10}{*}{ 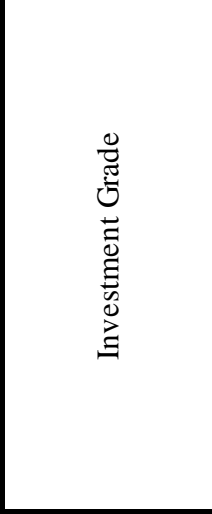 } & 21 \\
\hline \multirow{3}{*}{ High quality } & $\mathrm{AA}+$ & Aa1 & & 20 \\
\hline & $\mathrm{AA}$ & $\mathrm{Aa} 2$ & & 19 \\
\hline & AA- & Aa3 & & 18 \\
\hline \multirow{3}{*}{$\begin{array}{l}\text { Strong } \\
\text { payment } \\
\text { capacity }\end{array}$} & $\mathrm{A}+$ & $\mathrm{A} 1$ & & 17 \\
\hline & $\mathrm{A}$ & $\mathrm{A} 2$ & & 16 \\
\hline & A- & $\mathrm{A} 3$ & & 15 \\
\hline \multirow{3}{*}{$\begin{array}{l}\text { Adequate } \\
\text { payment } \\
\text { capacity }\end{array}$} & $\mathrm{BBB}+$ & Baa1 & & 14 \\
\hline & BBB & $\mathrm{Baa} 2$ & & 13 \\
\hline & BBB- & Baa3 & & 12 \\
\hline \multirow{3}{*}{$\begin{array}{l}\text { Likely to fulfil } \\
\text { obligations, } \\
\text { ongoing } \\
\text { uncertainty }\end{array}$} & $\mathrm{BB}+$ & $\mathrm{Ba} 1$ & \multirow{12}{*}{ 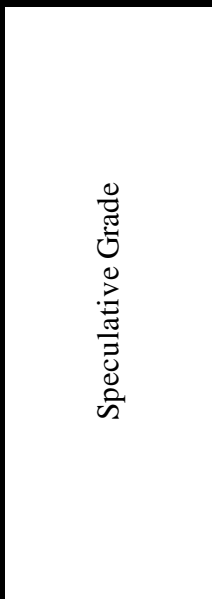 } & 11 \\
\hline & $\mathrm{BB}$ & $\mathrm{Ba} 2$ & & 10 \\
\hline & BB- & $\mathrm{Ba} 3$ & & 9 \\
\hline \multirow{3}{*}{$\begin{array}{l}\text { High-risk } \\
\text { obligations }\end{array}$} & $\mathrm{B}+$ & $\mathrm{B} 1$ & & 8 \\
\hline & $\mathrm{B}$ & $\mathrm{B} 2$ & & 7 \\
\hline & B- & B3 & & 6 \\
\hline \multirow{3}{*}{$\begin{array}{l}\text { Vulnerable to } \\
\text { default }\end{array}$} & $\mathrm{CCC}+$ & Caa1 & & 5 \\
\hline & $\mathrm{CCC}$ & $\mathrm{Caa} 2$ & & 4 \\
\hline & $\mathrm{CCC}-$ & $\mathrm{Caa} 3$ & & 3 \\
\hline \multirow{3}{*}{$\begin{array}{lll}\text { Near or } & \text { in } \\
\text { bankruptcy } & \text { or } \\
\text { default } & \end{array}$} & $\mathrm{CC}$ & $\mathrm{Ca}$ & & \multirow{2}{*}{2} \\
\hline & C & C & & \\
\hline & $\mathrm{D}$ & $\mathrm{D}$ & & 1 \\
\hline
\end{tabular}

\subsection{Explanatory Variables}

In line with the existing literature, some set of macroeconomic variables and qualitative variables were identified as the determinants of emerging markets SCRs. The macroeconomic variables include:

1) GDP growth rate (Real): This variable is used to measure the economy growth of a country which gives an indicator of how easily a country can pay its debt.

Hypothesis - Positive effect:

$H_{1}$ : all other variables held constant, increase in GDP growth rate will lead to increase in SCRs.

2) GDP per capita: This is used to measure the economic performance of a country and it also reflects the debt repayment ability of a country.

Hypothesis - Positive effect:

$H_{1}$ : all other variables held constant, increase in GDP per capita will lead to increase in SCRs.

3) Inflation: This measures the rate at which the price of goods and services increases which invariably lead to reduction in the currency purchasing power. High inflation depicts that there is economic.

Hypothesis - Negative effect:

$H_{1}$ : all other variables held constant, increase in inflation will lead to decrease in SCRs.

4) External debt: The higher the external debt of a country, the greater the default risk.

Hypothesis - Negative effect:

$H_{1}$ : all other variables held constant, increase in external debt will lead to decrease in SCRs. 
5) Reserves: This measures the liquidity of a country, which indicate its ability in honouring its foreign currency obligation. High foreign reserves imply low default risk.

Hypothesis - Positive effect:

$H_{1}$ : all other variables held constant, increase in reserves will lead to increase in SCRs.

6) Government debt: High government debt is associated with high default risk. This is because high interest rate would be required to service the debt.

Hypothesised - Negative effect:

$H_{1}$ : all other variables held constant, increase in government debt will lead to decrease in SCRs.

7) Current account balance: High current account deficit can indicate an increase in a country's net foreign asset. This can lead to growth and invariably improve the sustainability of the country.

Hypothesis - Positive effect:

$H_{1}$ : all other variables held constant, increase in current account balance will lead to increase in SCRS.

Also, for qualitative variables, the study employed the average of the six worldwide governance indicators. These are Government Effectiveness, Rule of Law, Control of Corruption, Regulatory Quality, Political Stability and Absence of Violence/Terrorism, Voice and Accountability.

8) Governance indicator reflects the willingness of the government to service its debt. Hence, a higher value is associated with low default risk.

Hypothesis - Positive effect:

$H_{1}$ : all other variables held constant, increase in the value of governance indicators will lead to increase in SCRs.

The average of the six worldwide governance indicators was used because of the high correlation that exists between the variables, which may result in multicollinearity. The summary of all the explanatory variables is presented in table 2 .

Table 2. Explanatory Variables and Sources

\begin{tabular}{|c|c|c|c|c|}
\hline Variable Name & Variable Code & Variable Descriptor & Units & Sources \\
\hline $\begin{array}{l}\text { GDP Growth } \\
\text { Rate }\end{array}$ & NGDP_RPCH & $\begin{array}{l}\text { Gross domestic product, } \\
\text { constant prices }\end{array}$ & Percent change & IMF (WEO) \\
\hline GDP Per Capita & NY.GDP.PCAP. KD & $\begin{array}{l}\text { GDP per capita (constant } \\
\text { 2010) }\end{array}$ & US dollars & WB (WDI) \\
\hline Inflation & PCPIPCH & $\begin{array}{l}\text { Inflation, average consumer } \\
\text { prices }\end{array}$ & Percent change & IMF (WEO) \\
\hline External Debt & DT.DOD.DECT.EX.ZS & External debt stocks & $\begin{array}{c}\% \text { of exports of goods, } \\
\text { services and primary } \\
\text { income }\end{array}$ & WB (WDI) \\
\hline Reserves & TOTRESV & Total Reserves, & US dollars & WB (GEM) \\
\hline $\begin{array}{l}\text { Government } \\
\text { Debt }\end{array}$ & GGXWDG_NGDP & $\begin{array}{c}\text { General government gross } \\
\text { debt }\end{array}$ & Percent of GDP & IMF (WEO) \\
\hline $\begin{array}{l}\text { Current } \\
\text { Account } \\
\text { Balance }\end{array}$ & BCA_NGDPD & Current account balance & Percent of GDP & IMF (WEO) \\
\hline $\begin{array}{l}\text { Governance } \\
\text { Indicators: }\end{array}$ & & $\begin{array}{l}\text { Average of the governance } \\
\text { Indicators: }\end{array}$ & \multirow{7}{*}{$\begin{array}{c}\text { The estimate gives the } \\
\text { country's score on the } \\
\text { aggregate indicator, in } \\
\text { units of a standard normal } \\
\text { distribution, i.e. ranging } \\
\text { from approximately }-2.5 \text { to } \\
2.5 \text {. }\end{array}$} & \multirow{7}{*}{ WB (WGI) } \\
\hline 1 & CC.EST & Control of Corruption & & \\
\hline 2 & GE.EST & Government Effectiveness & & \\
\hline 3 & PV.EST & $\begin{array}{c}\text { Political Stability and Absence } \\
\text { of Violence/Terrorism }\end{array}$ & & \\
\hline 4 & RQ.EST & Regulatory Quality & & \\
\hline 5 & RL.EST & Rule of Law & & \\
\hline 6 & VA.EST & Voice and Accountability & & \\
\hline
\end{tabular}




\subsection{Econometric Approach}

There are two strands of econometric approach in the literature (Afonso et al., 2011; Ederm \& Varli, 2014). These are Linear regression methods and ordered response models. The use of linear regression method in representing ratings numerically is very easy and straight forward (Afonso et al., 2011). It can be used for both cross-section data and panel data. However, it has been critiqued for assuming that the variation between two rating categories is the same (Ederm \& Varli, 2014). Consequently, ordered response model was adopted in order to overcome linear regression model criticisms (Bissoondoyal-Bheenick, 2005; Ederm \& Varli, 2014).

In modelling the SCRs of the emerging markets selected, the econometric model is presented as follow:

$$
y_{\text {it }}=\alpha+\beta x_{i t}+\mu_{\text {it }}
$$

$\mathrm{y}_{\mathrm{it}}$ denote the emerging market's rating that is linearly transformed into numbers. Whereas " $\mathrm{i}$ " and " $\mathrm{t}$ " signifies the country index (i.e. 1..,20) and time period (i.e. 2001...,2015) respectively. Also, $\beta$ signify the coefficient vector, and $\mathrm{x}_{\mathrm{it}}$ signify the explanatory variables vector. Likewise, $\alpha_{\mathrm{i}}$ signify each country error terms, while $\mu_{\mathrm{it}}$ signify the disturbance term, which is assumed to be independent of the countries and time periods.

Furthermore, in analysing the data and stated hypothesis, statistical tools such as SPSS and Excel are used. Similarly, in explaining the properties of the variables that formed the OLS regression models, descriptive statistics is employed. This measures the central tendency and the variability of the analysed data which include the mean, standard deviation, minimum and maximum variables kurtosis, and skewness. Also, statistical tests such as normality, Multicollinearity, correlation and pooled OLS regression were carried out to explain the relationship between SCRs and the identified explanatory variables.

\section{Presentation and Analysis of the Descriptive Statistics}

This gives a description of the data employed in relation to the mean, standard deviation, skewness, and kurtosis. Thereafter, the normality of the data will be discussed before the presentation of the correlation coefficient matrix. Also, the collinearity statistics test will be examined. In general, graphs and tables will be used in the presentation of data in order to summarize its characteristics.

\subsection{Descriptive Statistics}

The study builds its database on 20 emerging markets, covering the period of 2001-2015 (i.e. 15years). In total, 300 observations were achieved, where 1 observation denotes a particular year of an emerging market.

Table 3. Descriptive statistics (SPSS)

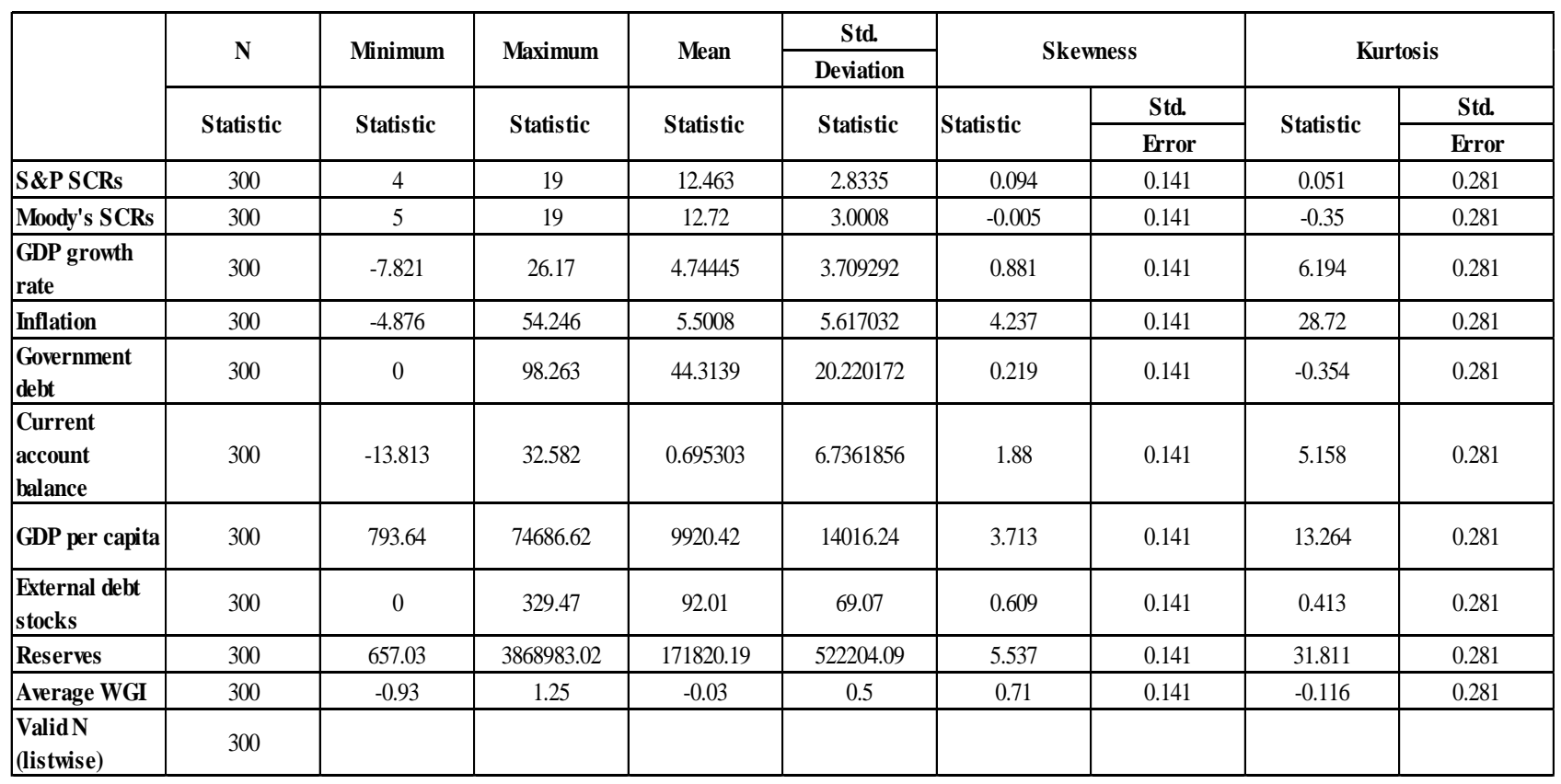


Table 3 shows the summary of the descriptive statistics of both the explained and explanatory variables. Likewise, table 4 presents the region covered by these variables.

Table 4. Countries classification

\begin{tabular}{|l|c|c|c|c|}
\hline Americas & Europe & Africa & Middle East & Asia \\
\hline Brazil & Russia & Morocco & Qatar & China \\
\hline Chile & Hungary & South Africa & & India \\
\hline Colombia & Poland & Egypt & & Indonesia \\
\hline Mexico & Turkey & & & Malaysia \\
\hline Peru & Romanian & & & Philippines \\
\hline & & & & Thailand \\
\hline
\end{tabular}

\subsubsection{Explained Variables}

First is the sovereign credit ratings issued by S\&P. This ranges from 4 to 19 , where 4 (i.e. CCC) is the minimum rating and 19 (i.e. AA) is the maximum rating. The average rating of the 20 emerging markets considered is 12.5 with the standard deviation of 2.8. That is, the average rating lies between BBB- and BBB, which falls in the investment grade category. This suggests that on the average, the emerging markets have adequate payment capacity and hence, their probability of default is low. Table 5 shows the classification of S\&P's rating for the selected samples.

Table 5. S\&P's rating classification (Author generated)

\begin{tabular}{|l|l|l|l|l|l|l|l|l|l|l|l|l|l|l|l|l|}
\hline & $\mathbf{2}$ & $\mathbf{2}$ & $\mathbf{2}$ & $\mathbf{2}$ & $\mathbf{2}$ & $\mathbf{2}$ & $\mathbf{2}$ & $\mathbf{2}$ & $\mathbf{2}$ & $\mathbf{2}$ & $\mathbf{2}$ & $\mathbf{2}$ & $\mathbf{2}$ & $\mathbf{2}$ & $\mathbf{2}$ & $\mathbf{T}$ \\
& $\mathbf{0}$ & $\mathbf{0}$ & $\mathbf{0}$ & $\mathbf{0}$ & $\mathbf{0}$ & $\mathbf{0}$ & $\mathbf{0}$ & $\mathbf{0}$ & $\mathbf{0}$ & $\mathbf{0}$ & $\mathbf{0}$ & $\mathbf{0}$ & $\mathbf{0}$ & $\mathbf{0}$ & $\mathbf{0}$ & $\mathbf{0}$ \\
& $\mathbf{0}$ & $\mathbf{0}$ & $\mathbf{0}$ & $\mathbf{0}$ & $\mathbf{0}$ & $\mathbf{0}$ & $\mathbf{0}$ & $\mathbf{0}$ & $\mathbf{0}$ & $\mathbf{1}$ & $\mathbf{1}$ & $\mathbf{1}$ & $\mathbf{1}$ & $\mathbf{1}$ & $\mathbf{1}$ & $\mathbf{1}$ \\
$\mathbf{1}$ & $\mathbf{2}$ & $\mathbf{3}$ & $\mathbf{4}$ & $\mathbf{5}$ & $\mathbf{6}$ & $\mathbf{7}$ & $\mathbf{8}$ & $\mathbf{9}$ & $\mathbf{0}$ & $\mathbf{1}$ & $\mathbf{2}$ & $\mathbf{3}$ & $\mathbf{4}$ & $\mathbf{5}$ & $\mathbf{1}$ \\
\hline $\begin{array}{l}\text { Investment } \\
\text { Grade }\end{array}$ & 11 & 11 & 10 & 12 & 14 & 15 & 17 & 17 & 17 & 17 & 17 & 17 & 18 & 18 & 19 & 230 \\
\hline $\begin{array}{l}\text { Speculative } \\
\text { Grade }\end{array}$ & 9 & 9 & 10 & 8 & 6 & 5 & 3 & 3 & 3 & 3 & 3 & 3 & 2 & 2 & 1 & 70 \\
\hline
\end{tabular}

Also, S\&P ratings have a skewness of 0.094 . That is, the distribution is positively skewed, which indicate that the mean is greater than the median, which is subsequently greater than the mode $(0.094>0)$. Hence, there are very few high observations. In addition, S\&P ratings have a positive kurtosis of 0.051 . This indicates that the distribution is less peaked $(0.051<3)$ and thus, the distribution is referred to as being platykurtic in nature. The descriptive statistic of $S \& P$ is graphically shown in Figure 2.

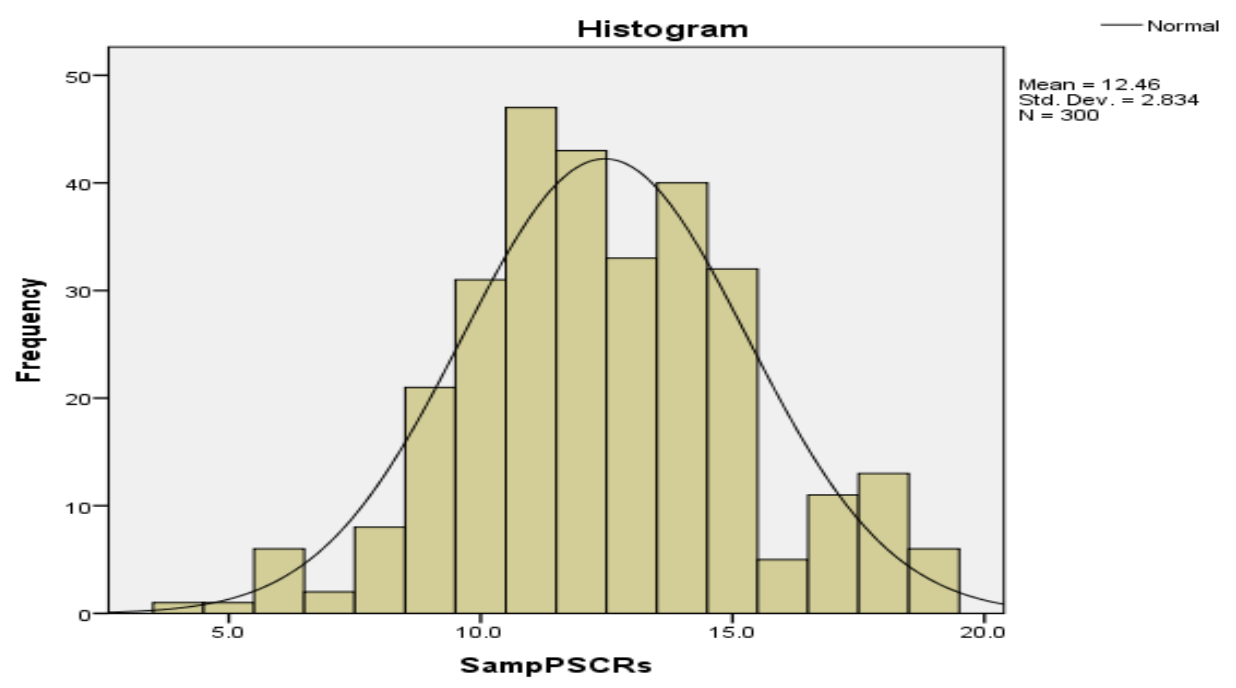

Figure 2. S\&P's Histogram (Author generated) 
Sovereign credit rating issued by Moody also ranges from 5 to 19, with 5 (i.e. Caa1) being the minimum and 19 (i.e. Aa2) being the maximum rating. The average rating is 12.7 with a standard deviation of 3 . The average rating also lies between BBB- and BBB, which falls in the investment grade category. In general, comparing the average rating of $\mathrm{S} \& \mathrm{P}$ and Moody depicts adequate payment capacity. However, the default probability of $\mathrm{S} \& \mathrm{P}$ is a bit lower than that of Moody. Table 6 shows the classification of Moody's rating for the selected samples.

Table 6. Moody's rating classification (Authors generated)

\begin{tabular}{|l|l|l|l|l|l|l|l|l|l|l|l|l|l|l|l|l|}
\hline & $\mathbf{2}$ & $\mathbf{2}$ & $\mathbf{2}$ & $\mathbf{2}$ & $\mathbf{2}$ & $\mathbf{2}$ & $\mathbf{2}$ & $\mathbf{2}$ & $\mathbf{2}$ & $\mathbf{2}$ & $\mathbf{2}$ & $\mathbf{2}$ & $\mathbf{2}$ & $\mathbf{2}$ & $\mathbf{2}$ & $\mathbf{T}$ \\
& $\mathbf{0}$ & $\mathbf{0}$ & $\mathbf{0}$ & $\mathbf{0}$ & $\mathbf{0}$ & $\mathbf{0}$ & $\mathbf{0}$ & $\mathbf{0}$ & $\mathbf{0}$ & $\mathbf{0}$ & $\mathbf{0}$ & $\mathbf{0}$ & $\mathbf{0}$ & $\mathbf{0}$ & $\mathbf{0}$ & $\mathbf{0}$ \\
& $\mathbf{0}$ & $\mathbf{0}$ & $\mathbf{0}$ & $\mathbf{0}$ & $\mathbf{0}$ & $\mathbf{0}$ & $\mathbf{0}$ & $\mathbf{0}$ & $\mathbf{0}$ & $\mathbf{1}$ & $\mathbf{1}$ & $\mathbf{1}$ & $\mathbf{1}$ & $\mathbf{1}$ & $\mathbf{1}$ & $\mathbf{t}$ \\
& $\mathbf{1}$ & $\mathbf{2}$ & $\mathbf{3}$ & $\mathbf{4}$ & $\mathbf{5}$ & $\mathbf{6}$ & $\mathbf{7}$ & $\mathbf{8}$ & $\mathbf{9}$ & $\mathbf{0}$ & $\mathbf{1}$ & $\mathbf{2}$ & $\mathbf{3}$ & $\mathbf{4}$ & $\mathbf{5}$ & $\mathbf{a}$ \\
\hline
\end{tabular}

Furthermore, Moody rating has a skewness of -0.005 . That is, the distribution is negatively skewed, which signify that the mean is less than the median, which is subsequently less than the mode $(-0.005<0)$. In addition, Moody's rating has a negative kurtosis of -0.35 . This also indicates that the distribution is less peaked because it is less than 3. However, S\&P rating distribution is more peaked than that of Moody. In order words, Moody's rating distribution is also platykurtic in nature. The descriptive statistic of Moody is graphically shown in Figure 3.

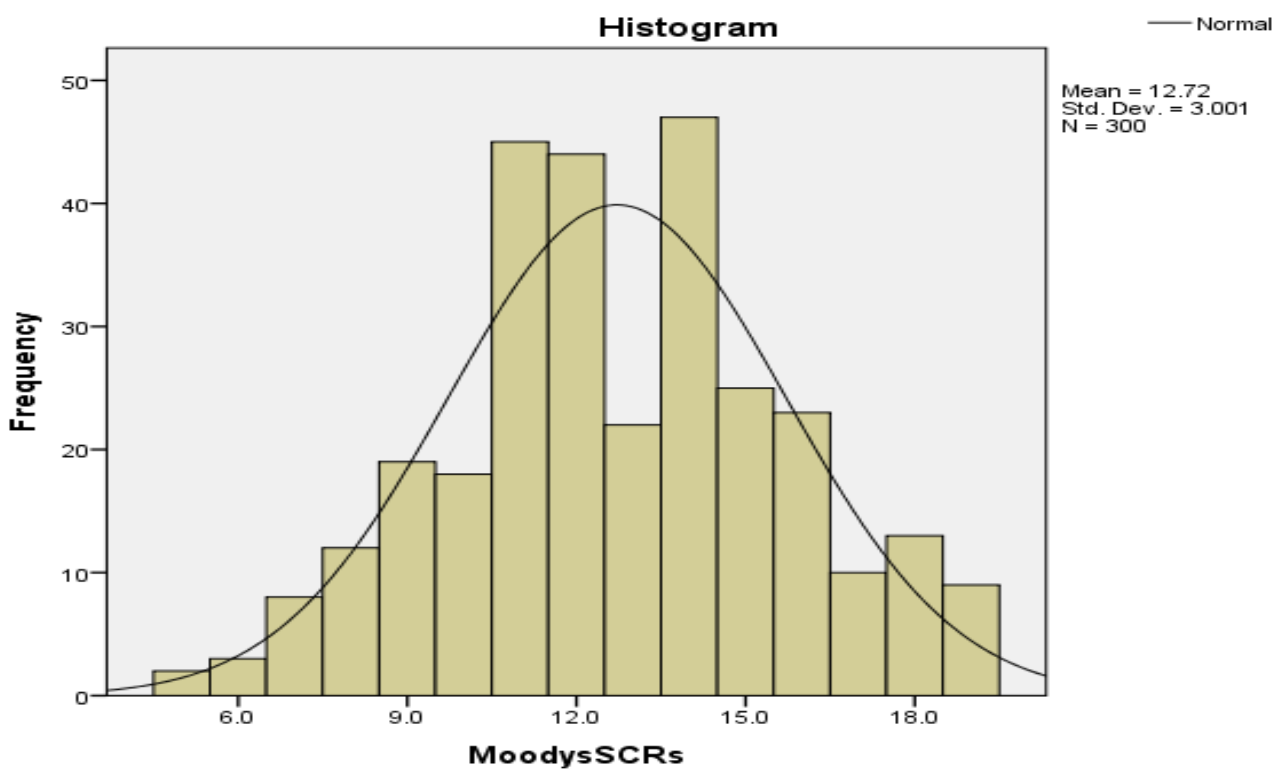

Figure 3. Moody's Histogram (Author generated)

\subsubsection{Explanatory Variables}

GDP growth rate has a minimum of $-7.82 \%$ and a maximum of $26.17 \%$. The average mean is about $4.75 \%$ with a standard deviation of $3.71 \%$. 


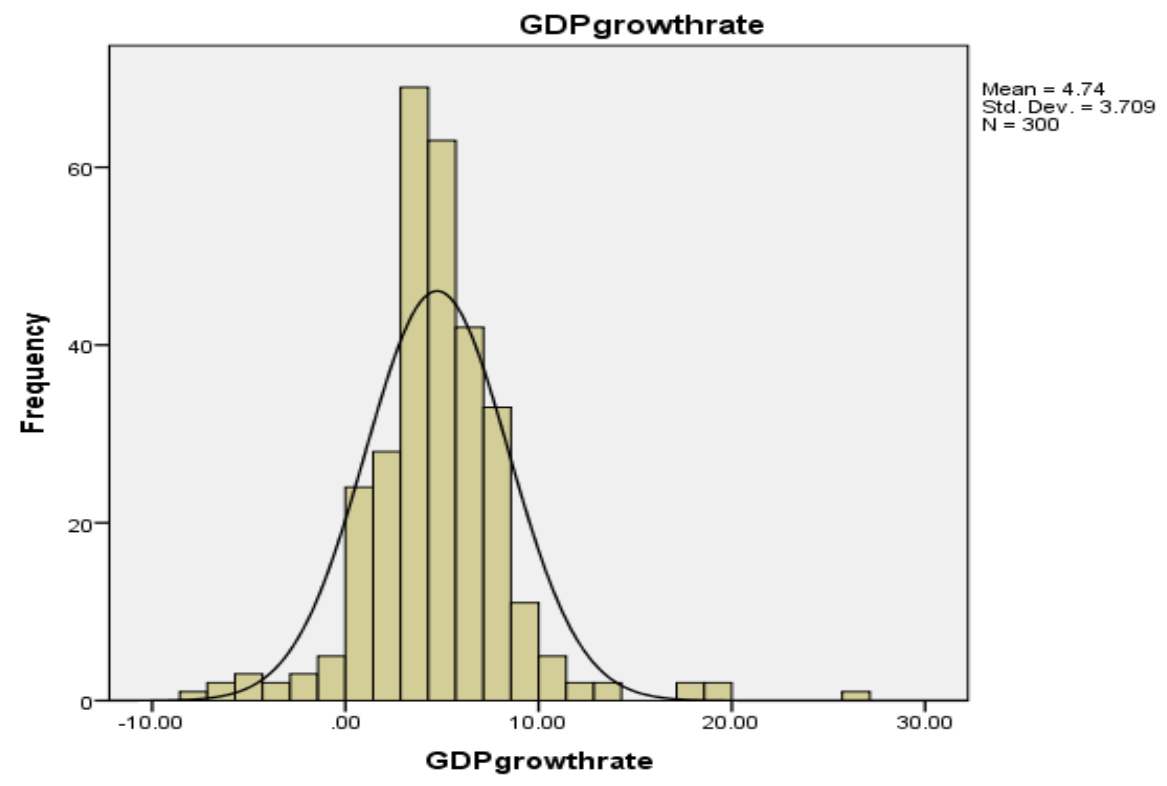

Figure 4. Histogram of GDP growth rate (Author generated)

Also, it has a skewness and kurtosis of 0.88 and 6.19 respectively. This suggests that the mean is greater than the median, which is subsequently greater than the mode. So, there is few high observation and the distribution is leptokurtic in nature. Denoting that the distribution is more peaked than the normal distribution (6.19>3). This is presented graphically in figure 4 .

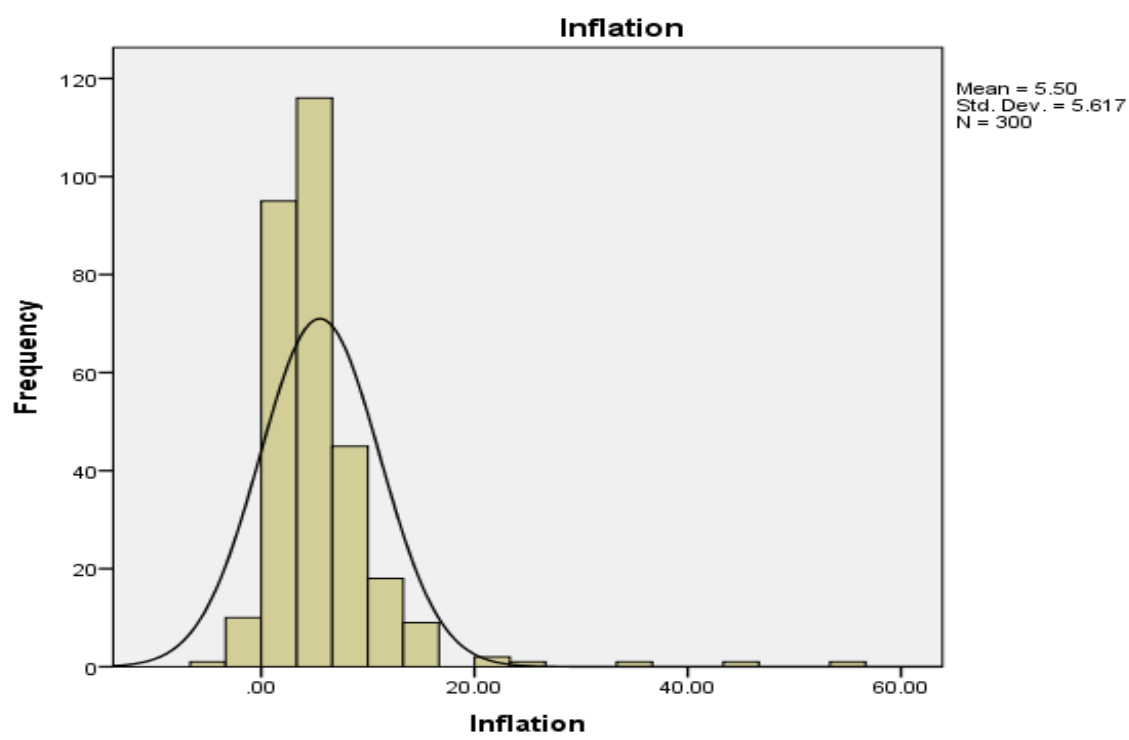

Figure 5. Inflation Histogram (Author generated)

The inflation rate of the emerging markets ranges from a minimum of $-4.88 \%$ to a maximum of $54.25 \%$. Its average mean is about $5.50 \%$ with a standard deviation of $5.62 \%$. It also has a positive skewness and kurtosis of 4.24 and 28.72 respectively. This suggests that its mean is greater than the median, which is also greater than the mode. Hence, there are very few high observations $(4.24>0)$. Also, the distribution is leptokurtic in nature (28.72>3), which indicates that the distribution is highly peaked. This is illustrated in figure 5 . 


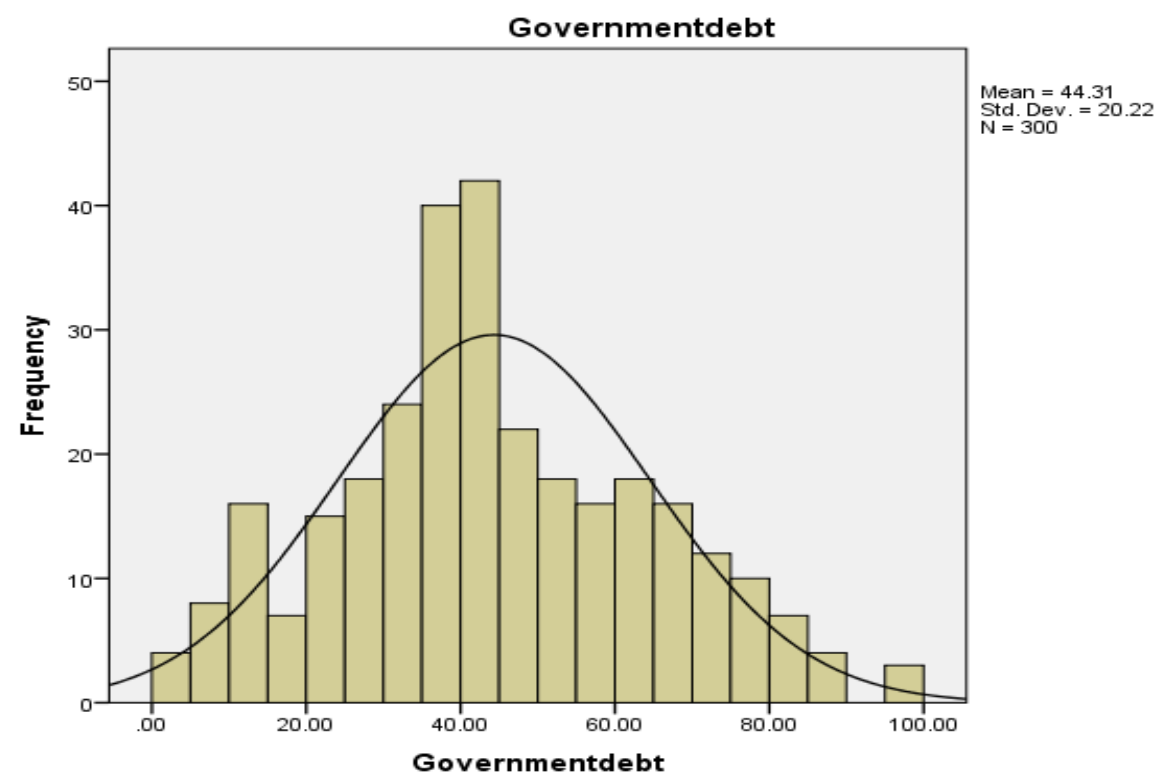

Figure 6. Government debt Histogram (Author generated)

Government debt ranges from a minimum of $0.00 \%$ to a maximum of $98.26 \%$. Its average mean is around $44.31 \%$ with a standard deviation of $20.22 \%$. It also has a positive skewness of 0.22 and a negative kurtosis of -0.35 . This suggests that there are very few high observations (i.e. mean $>$ median $>$ mode). It also indicates that the distribution is less peaked and so, it is platykurtic in nature. This is presented in figure 6.

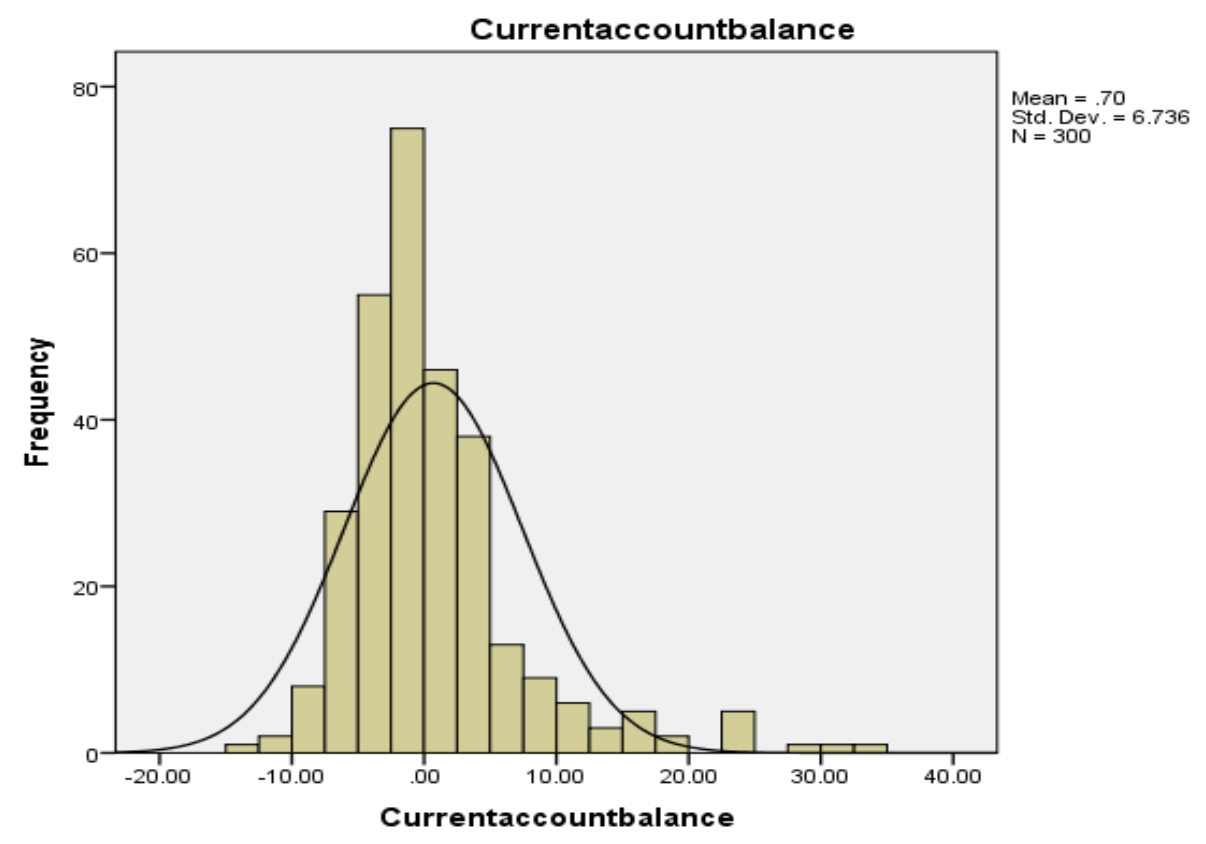

Figure 7. Current Account Balance Histogram (Author generated)

Current account balance ranges from a minimum of $-13.81 \%$ to a maximum of $32.58 \%$. Its average mean is about $0.695 \%$ with a standard deviation of $6.74 \%$. It also has a positive skewness and kurtosis of 1.88 and 5.16 respectively. This suggests that its mean is greater than the median, which is also greater than the mode. Hence, there are very few high observations $(1.88>0)$. Also, the distribution is leptokurtic in nature $(5.16>3)$, which indicates that the distribution is more peaked. This is illustrated in figure 7. 


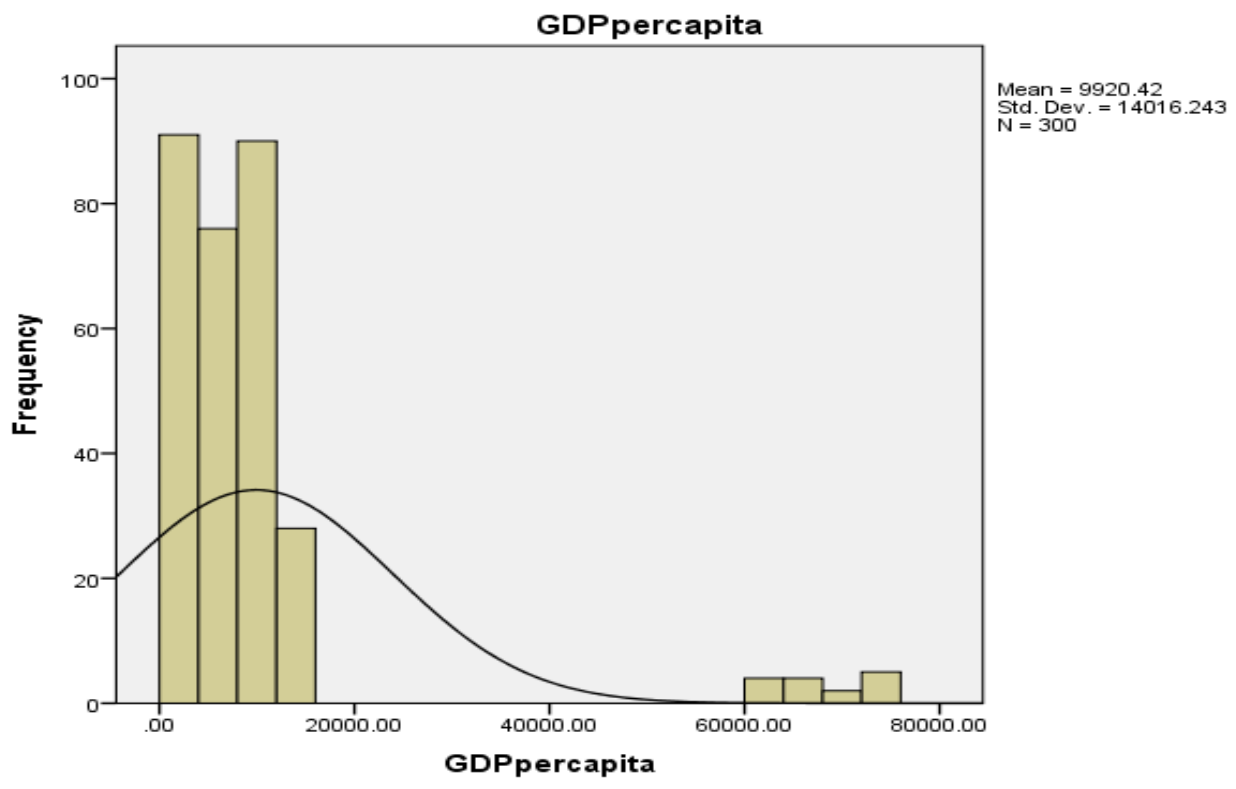

Figure 8. GDP per capita Histogram (Author generated)

The GDP per capita of the emerging markets ranges from a minimum of $\$ 793.64$ to a maximum of $\$ 74,686.62$. Its average mean is about $9,920.42$ with a standard deviation of $\$ 14,016.24$. It also has a positive skewness and kurtosis of 3.71 and 13.26 respectively. This suggests that there are very few high observations (i.e. mean>median>mode). It also indicates that the distribution is highly peaked and so, it is leptokurtic in nature. This is presented in figure 8 .

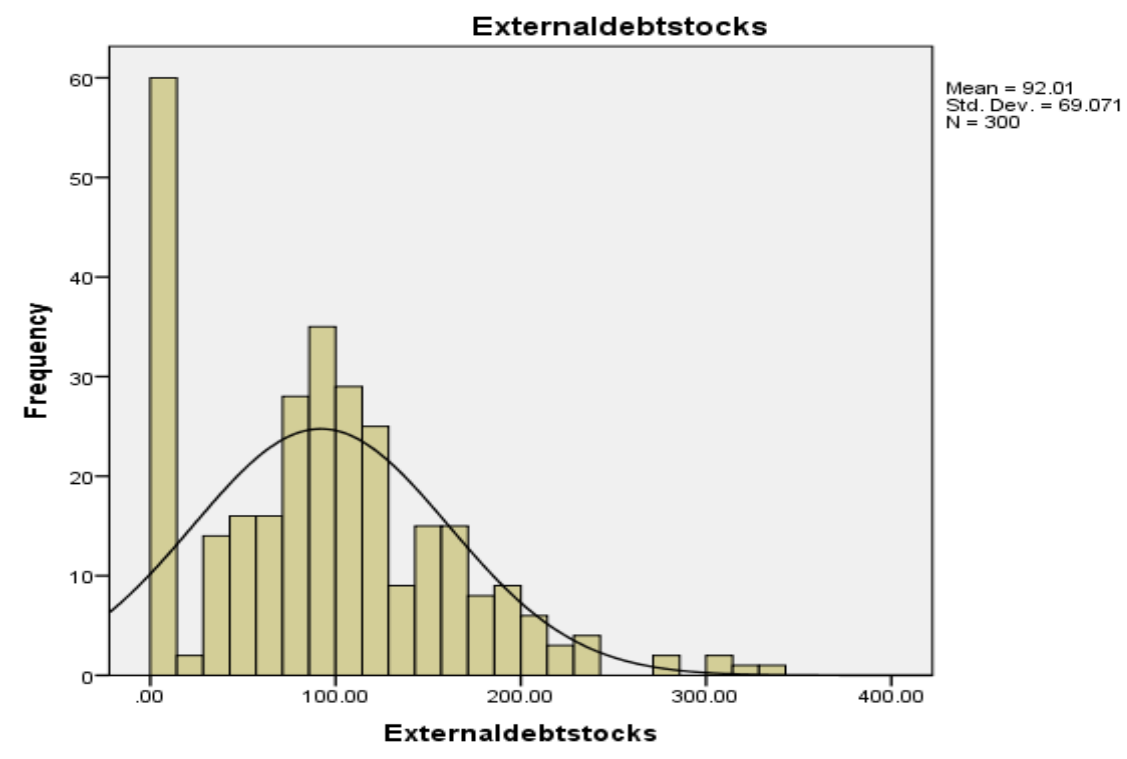

Figure 9. External debt histogram (Author generated)

External debt ranges from a minimum of 0.00 to a maximum of 329.47. Its average mean is around 92.01 with a standard deviation of 69.07. It also has a positive skewness of 0.61 and kurtosis of 0.41 . This suggests that there are very few high observations (i.e. mean $>$ median $>$ mode). It also indicates that the distribution is less peaked and so, it is platykurtic in nature. This is presented in figure 9. 


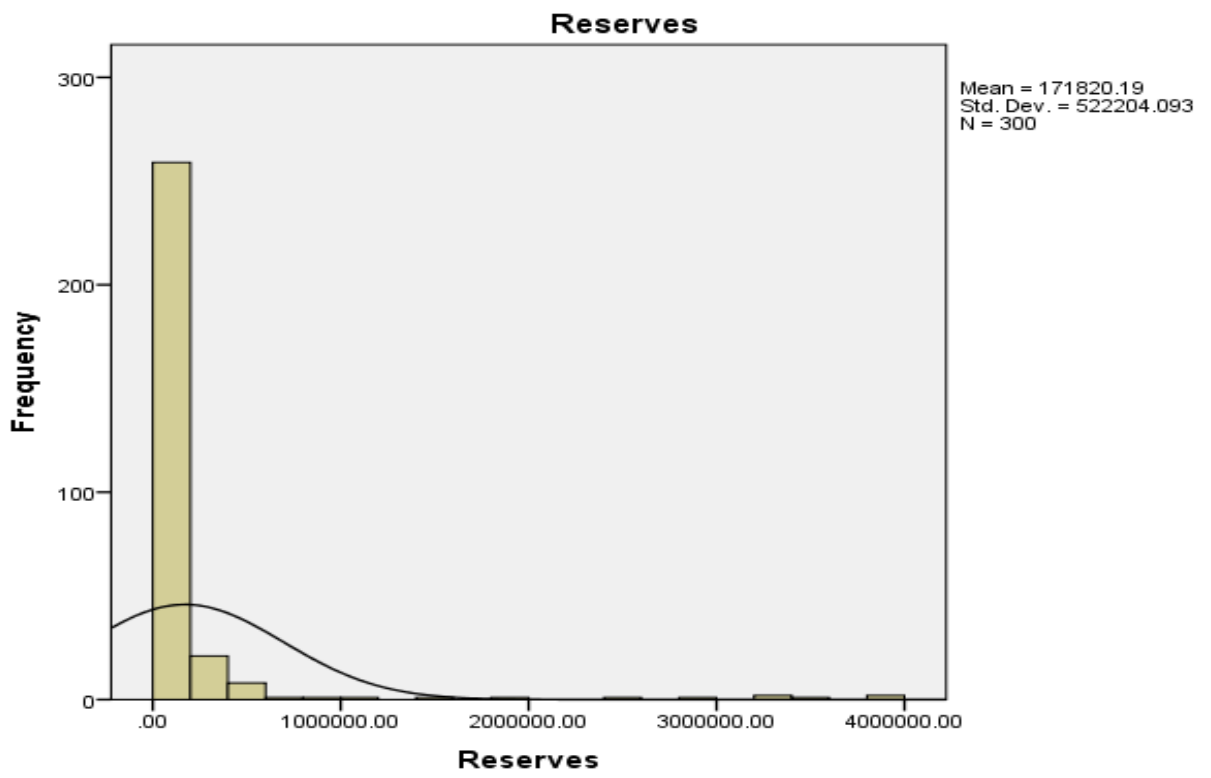

Figure 10. Reserves Histogram (Author generated)

Reserves range from a minimum of 657.03 to a maximum of $3,868,983.02$. Its average mean is around $171,820.18$ with a standard deviation of 522,204.09. It also has a positive skewness of 5.54 and kurtosis of 31.81. This suggests that there are very few high observations (i.e. mean $>$ median $>$ mode). It also indicates that the distribution is highly peaked and so, it is leptokurtic in nature. This is presented in figure 10.

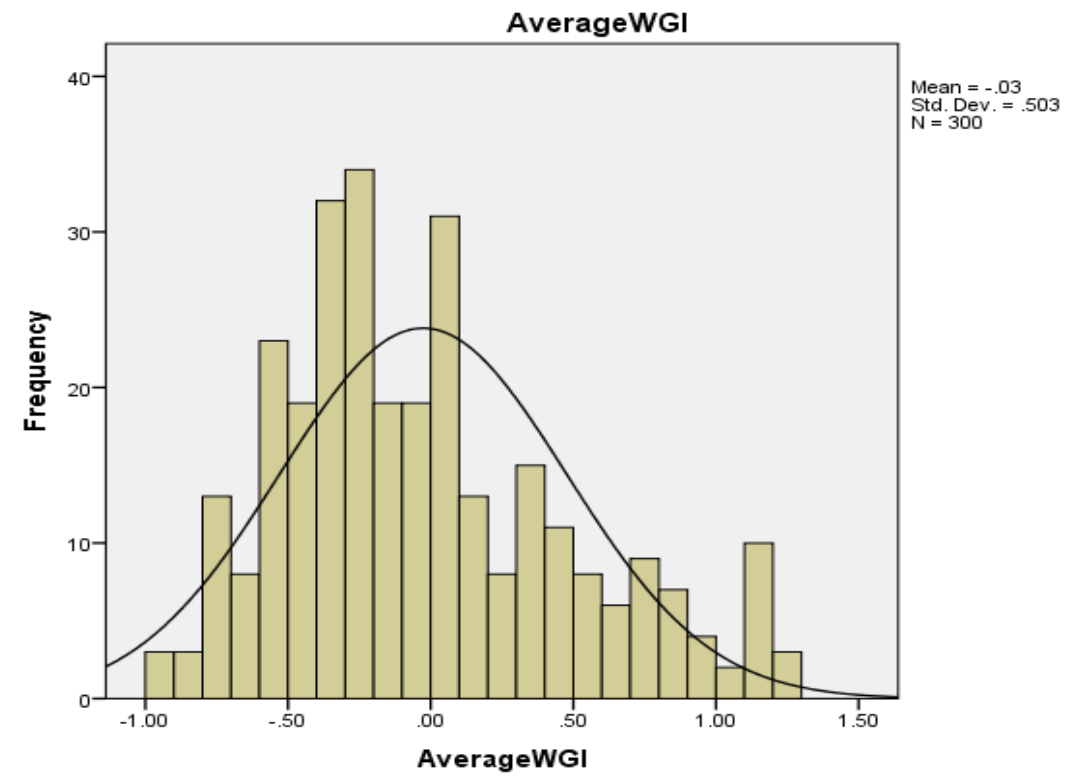

Figure 11. Average WGI Histogram (Author generated)

Average world governance indicators range from a minimum of -0.93 to a maximum of 1.25 . Its average mean is around -0.027 with a standard deviation of 0.50 . It also has a positive skewness of 0.71 and a negative kurtosis of -0.12 . This suggests that there are very few high observations (i.e. mean $>$ median $>$ mode). It also indicates that the distribution is less peaked and so, it is platykurtic in nature. This is illustrated in figure 11.

\subsection{Normality Test}

The normality of the explained variable as required by parametric statistics is examined through the skewness and kurtosis of the explained variable, as well as the use of the histogram and normal Q-Q plot. S\&P ratings have a skewness of $0.094(\mathrm{SE}=0.141)$ and kurtosis of 0.051 ( $\mathrm{SE}=0.281)$ whereas, Moody's rating has a skewness of $-0.005(\mathrm{SE}=0.141)$ and a kurtosis of $-0.350(\mathrm{SE}=0.281)$. This suggests that the distribution is assumed to be 
approximately normally because all the $\mathrm{z}$ values fall within $+/-1.96$ (Doane and Seward, 2011). However, the data are a little bit skewed and kurtosis, but they do not significantly differ from a normal distribution.

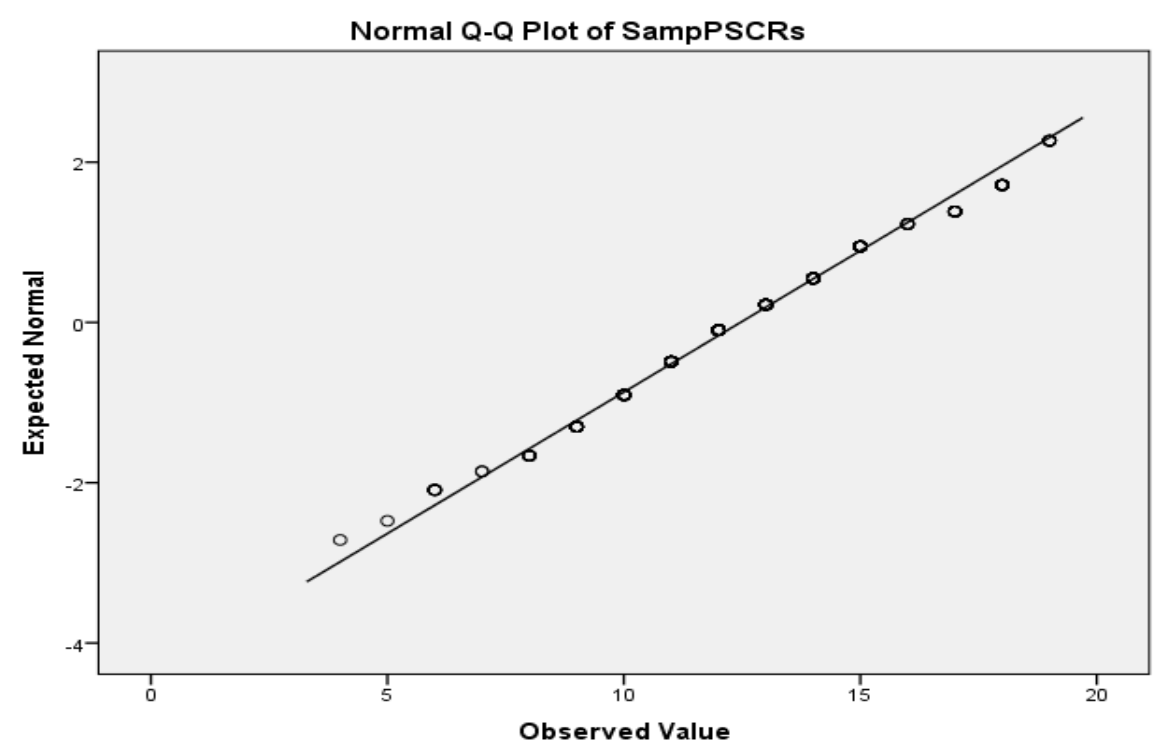

Figure 12. S\&P Q-Q Plot (Author generated)

Furthermore, the Q-Q plot of both S\&P and Moody also indicate that the data set is approximately normally distributed. These plots are presented in figure 12 and 13 respectively.

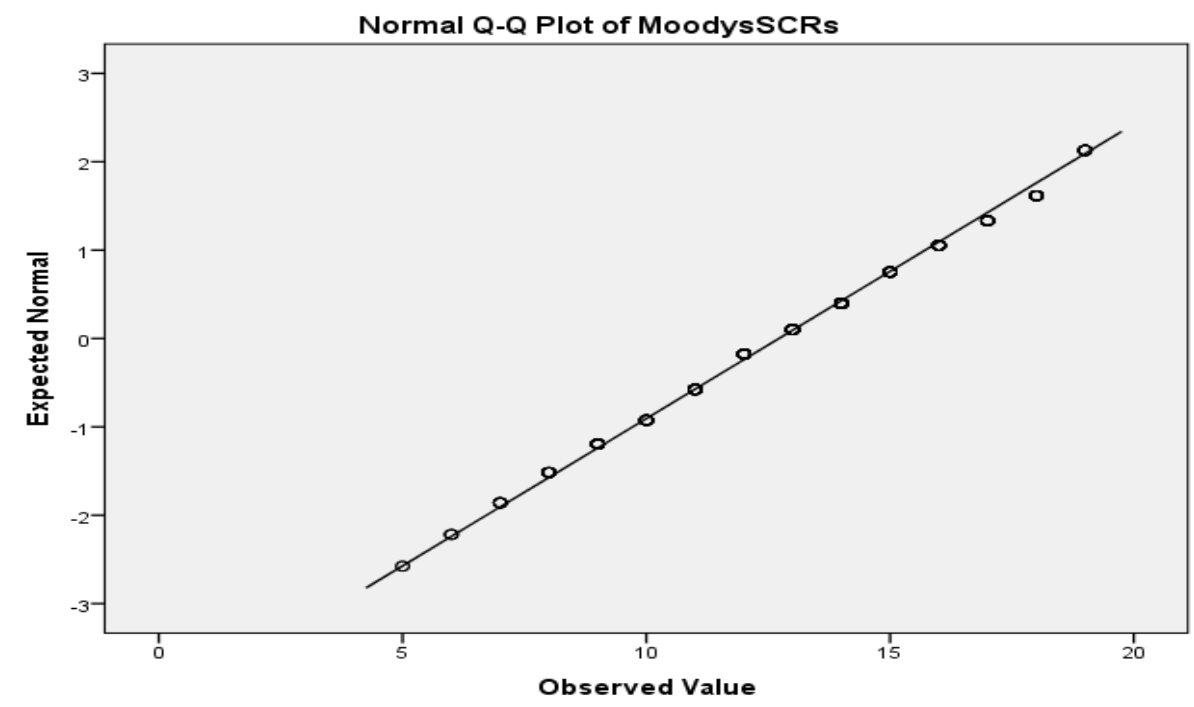

Figure 13. Moody Q-Q plot (Author generated)

In a normally distributed data, all the dots should be on the straight line. Therefore, it is assumed that the data set is approximately normal because almost all the dots lie reasonably close to the line of best fit.

\subsection{Correlation Analysis}

The Pearson's correlation matrix of the explanatory variables is shown in table 7. This gives the overview of the linear relationship between the explanatory variables. The GDP growth rate is negatively correlated with government debt (-0.173) and external debt $(-0.202)$ whereas, it has a positive correlation with current account balance (0.322), GDP per capita (0.296) and reserves (0.202). All at a significant level of 0.01. Also, inflation is positively correlated with external debt $(0.275)$ and negatively correlated with the average of WGI (-0.193) at the same significant level of 0.01 . Surprisingly, government debt has a negative relationship with both current account balance and the average of WGI at a coefficient of -0.136 which is significant at 0.05 . Meanwhile, government debt has a positive correlation with external debt (0.195) and a negative correlation with GDP per 
capital (-0.195) at 0.01 significant level.

Furthermore, at 0.01 significant level, current account balance has a high positive correlation with GDP per capital (0.641) and a negative correlation with external debt (-0.328). Also, GDP per capita and the average of WGI is positively correlated (0.417) at 0.01 significant level.

Table 7. Pearson correlation matrix (SPSS)

\begin{tabular}{|c|c|c|c|c|c|c|c|c|c|}
\hline \multicolumn{10}{|c|}{ Correlations } \\
\hline & & $\begin{array}{l}\text { GDP growth } \\
\text { rate }\end{array}$ & Inflation & $\begin{array}{c}\text { Government } \\
\text { debt }\end{array}$ & $\begin{array}{l}\text { Current } \\
\text { account } \\
\text { balance }\end{array}$ & GDP per capita & $\begin{array}{l}\text { External debt } \\
\text { stocks }\end{array}$ & Reserves & Average WGI \\
\hline \multirow{3}{*}{$\begin{array}{l}\text { GDP growth } \\
\text { rate }\end{array}$} & \begin{tabular}{|l|} 
Pearson \\
Correlation
\end{tabular} & 1 & -0.062 & $-.173 * *$ & $.322 * *$ & $.296 * *$ & $-.202 * *$ & $.202 * *$ & -0.06 \\
\hline & Sig. (2-tailed) & & 0.281 & 0.003 & 0 & 0 & 0 & 0 & 0.3 \\
\hline & $\mathrm{N}$ & 300 & 300 & 300 & 300 & 300 & 300 & 300 & 300 \\
\hline \multirow{3}{*}{ Inflation } & $\begin{array}{l}\text { Pearson } \\
\text { Correlation }\end{array}$ & -0.062 & 1 & 0.072 & -0.07 & -0.051 & $.275^{* *}$ & -0.073 & $-.193 * *$ \\
\hline & Sig. (2-tailed) & 0.281 & & 0.215 & 0.226 & 0.382 & 0 & 0.209 & 0.001 \\
\hline & $\mathrm{N}$ & 300 & 300 & 300 & 300 & 300 & 300 & 300 & 300 \\
\hline \multirow{3}{*}{$\begin{array}{l}\text { Government } \\
\text { debt }\end{array}$} & \begin{tabular}{|l} 
Pearson \\
Correlation \\
\end{tabular} & $-.173^{* *}$ & 0.072 & 1 & $-.136^{*}$ & $-.195^{* *}$ & $.195^{* *}$ & -0.103 & $-.136^{*}$ \\
\hline & Sig. (2-tailed) & 0.003 & 0.215 & & 0.019 & 0.001 & 0.001 & 0.074 & 0.019 \\
\hline & $\mathrm{N}$ & 300 & 300 & 300 & 300 & 300 & 300 & 300 & 300 \\
\hline \multirow{3}{*}{$\begin{array}{l}\text { Current } \\
\text { account } \\
\text { balance }\end{array}$} & \begin{tabular}{|l|} 
Pearson \\
Correlation
\end{tabular} & $.322 * *$ & -0.07 & $-.136^{*}$ & 1 & $.641 * *$ & $-.328 * *$ & 0.09 & 0.057 \\
\hline & \begin{tabular}{|l|} 
Sig. (2-tailed) \\
\end{tabular} & 0 & 0.226 & 0.019 & & 0 & 0 & 0.119 & 0.322 \\
\hline & $\mathrm{N}$ & 300 & 300 & 300 & 300 & 300 & 300 & 300 & 300 \\
\hline \multirow{3}{*}{ GDP per capita } & \begin{tabular}{|l|} 
Pearson \\
Correlation \\
\end{tabular} & $.296^{* *}$ & -0.051 & $-.195 * *$ & $.641 * *$ & 1 & $-.378 * *$ & -0.082 & $.417^{* *}$ \\
\hline & Sig. (2-tailed) & 0 & 0.382 & 0.001 & 0 & & 0 & 0.158 & 0 \\
\hline & $\mathrm{N}$ & 300 & 300 & 300 & 300 & 300 & 300 & 300 & 300 \\
\hline \multirow{3}{*}{$\begin{array}{l}\text { External } \\
\text { stocks }\end{array}$} & $\begin{array}{l}\text { Pearson } \\
\text { Correlation }\end{array}$ & $-.202 * *$ & $.275^{* *}$ & $.195 * *$ & $-.328^{* *}$ & $-.378^{* *}$ & 1 & $-.114^{*}$ & $-.508 * *$ \\
\hline & Sig. (2-tailed) & 0 & 0 & 0.001 & 0 & 0 & & 0.048 & 0 \\
\hline & $\mathrm{N}$ & 300 & 300 & 300 & 300 & 300 & 300 & 300 & 300 \\
\hline \multirow{3}{*}{ Reserves } & $\begin{array}{l}\text { Pearson } \\
\text { Correlation }\end{array}$ & $.202 * *$ & -0.073 & -0.103 & 0.09 & -0.082 & $-.114^{*}$ & 1 & $-.223 * *$ \\
\hline & Sig. (2-tailed) & 0 & 0.209 & 0.074 & 0.119 & 0.158 & 0.048 & & 0 \\
\hline & $\mathrm{N}$ & 300 & 300 & 300 & 300 & 300 & 300 & 300 & 300 \\
\hline \multirow{3}{*}{ Average WGI } & $\begin{array}{l}\text { Pearson } \\
\text { Correlation }\end{array}$ & -0.06 & $-.193 * *$ & $-.136^{*}$ & 0.057 & $.417^{* *}$ & $-.508^{* *}$ & $-.223 * *$ & 1 \\
\hline & Sig. (2-tailed) & 0.3 & 0.001 & 0.019 & 0.322 & 0 & 0 & 0 & \\
\hline & $\mathrm{N}$ & 300 & 300 & 300 & 300 & 300 & 300 & 300 & 300 \\
\hline \multicolumn{10}{|c|}{\begin{tabular}{|l|l}
$* *$ Correlation is significant at the 0.01 level (2-tailed). \\
\end{tabular}} \\
\hline *. Correlation is & significant at $t$ & 0.05 level (2-ta & & & & & & & \\
\hline
\end{tabular}

External debt has a negative relationship with reserves (-0.114) and average WGI (-0.508) at a significant level of 0.05 and 0.01 respectively. Similarly, reserves and average WGI are negatively correlated $(-0.223)$ at the significant level of 0.01 . However, considering the significance of all the correlated variables, the correlation between current account balance and GDP per capita (0.641), as well as the correlation between external debt and average WGI $(-0.508)$ has the highest coefficient. The correlation between all other variables are weak and hence requires no attention. As regards the two highly correlated ones, the multicollinearity test is analysed in the next section in order to avoid the violation of OLS assumption of non-autocorrelation.

\subsection{Multicollinearity}

Table 8 presents the analysis of the multicollinearity test for the explanatory variables, in order to establish that the variables are independent of each other. 
Table 8. Collinearity test (SPSS)

\begin{tabular}{|c|c|c|c|}
\hline \multirow{2}{*}{ Model } & \multicolumn{2}{|c|}{ Coefficients } \\
\cline { 2 - 4 } & \multicolumn{1}{|c|}{ Collinearity Statistics } \\
\hline \multirow{2}{*}{} & $\begin{array}{l}\text { GDP growth } \\
\text { rate }\end{array}$ & 0.8 & VIF \\
\hline & $\begin{array}{l}\text { Inflation } \\
\text { Government } \\
\text { debt }\end{array}$ & 0.907 & 1.25 \\
\hline $\begin{array}{l}\text { Current } \\
\text { account } \\
\text { balance }\end{array}$ & 0.923 & 1.083 \\
\hline $\begin{array}{l}\text { GDP per capita } \\
\text { External debt } \\
\text { stocks }\end{array}$ & 0.415 & 2.05 \\
\hline $\begin{array}{l}\text { Reserves } \\
\text { Average WGI }\end{array}$ & 0.577 & 1.733 \\
\hline
\end{tabular}

Tolerance explains how much of the specified predicted variable is not explained by other predicted variables in the model, whereas, VIF is an inverse of tolerance. The tolerance of current account and GDP per capital are the lowest, which are a bit below average. Consequently, there VIF are the highest. The overall VIF ranges from the minimum of 1.083 to a maximum of 2.412. However, the rule of thumb implies that the VIF greater than 5 indicate the existence of collinearity. In other words, it is assumed that there is no collinearity amongst the explanatory.

\section{Data Analysis and Discussion}

The pooled OLS regression result will be presented and critically analysed, by establishing the cause and effect relationship between SCRs and the identified explanatory variables. Also, the comparison between the two models employed (i.e. S\&P and Moody) will be examined in order to establish any differences between them.

\subsection{Regression Analysis}

The regression result used in identifying the determinant of sovereign credit rating are presented using two models. These include S\&P's ratings and Moody's ratings. The t- statistics, adjusted R2 value, p-values, as well the F statistics is used to evaluate the significant of the explanatory variables for each model. Each model is analysed separately before their comparison is discussed

\subsubsection{S\&P Regression Result}

The OLS regression result of S\&P is presented in table 9.

Table 9. S\&P Regression Result

\begin{tabular}{|l|c|c|c|c|c|}
\hline \multicolumn{7}{|c|}{ Model Summary } \\
\hline \multirow{2}{*}{ Model } & $\mathrm{R}$ & \multirow{2}{*}{ R Square } & Adjusted & \multirow{2}{*}{$\begin{array}{c}\text { Std. Error of } \\
\text { the Estimate }\end{array}$} & $\begin{array}{c}\text { Durbin- } \\
\text { Watson }\end{array}$ \\
\hline 1 & $.899 \mathrm{a}$ & 0.808 & 0.802 & 1.2597 & 0.539 \\
\hline
\end{tabular}

a. Predictors: (Constant), Average WGI, Current account balance, Government debt, Inflation, Reserves, GDP growth rate, External debt stocks, GDP per capita

b. Dependent Variable: S\&P SCRs 


\begin{tabular}{|c|c|c|c|c|c|c|}
\hline \multicolumn{7}{|c|}{ ANOVA } \\
\hline \multicolumn{2}{|l|}{ Model } & Sum of Squares & Df & Mean Square & $\mathbf{F}$ & Sig. \\
\hline \multirow{3}{*}{1} & Regression & 1938.798 & 8 & 242.35 & 152.715 & $.000 \mathrm{~b}$ \\
\hline & Residual & 461.799 & 291 & 1.587 & & \\
\hline & Total & 2400.597 & 299 & & & \\
\hline \multicolumn{7}{|c|}{ a. Dependent Variable: S\&P SCRs } \\
\hline \multicolumn{7}{|c|}{$\begin{array}{l}\text { b. Predictors: (Constant), Average WGI, Current account balance, Government debt, Inflation, Reserves, GDP growth rate, External debt } \\
\text { stocks, GDP per capita }\end{array}$} \\
\hline
\end{tabular}

\begin{tabular}{|c|c|c|c|c|c|c|}
\hline \multicolumn{7}{|c|}{ Coefficients } \\
\hline \multirow{3}{*}{ Model } & & \multirow{2}{*}{\multicolumn{2}{|c|}{$\begin{array}{c}\text { Unstandardized } \\
\text { Coefficients }\end{array}$}} & \multirow{3}{*}{$\begin{array}{c}\text { Standardized Coefficients } \\
\text { Beta }\end{array}$} & \multirow{3}{*}{$\mathbf{T}$} & \multirow{3}{*}{ Sig. } \\
\hline & & & & & & \\
\hline & & B & Std. Error & & & \\
\hline \multirow{9}{*}{1} & (Constant) & 15.024 & 0.268 & & 56.149 & $\mathbf{0}$ \\
\hline & GDP growth rate & 0.005 & 0.022 & 0.007 & 0.246 & 0.806 \\
\hline & Inflation & -0.112 & 0.014 & -0.221 & -8.202 & 0 \\
\hline & \begin{tabular}{|l|} 
Government debt \\
\end{tabular} & -0.033 & 0.004 & -0.239 & -8.925 & $\mathbf{0}$ \\
\hline & \begin{tabular}{|l|} 
Current account balance \\
\end{tabular} & 0.009 & 0.015 & 0.021 & 0.577 & 0.564 \\
\hline & GDP per capita & $4.63 \mathrm{E}-05$ & $\mathbf{0}$ & 0.229 & 5.732 & 0 \\
\hline & External debt stocks & -0.013 & 0.001 & -0.323 & -9.554 & $\mathbf{0}$ \\
\hline & Reserves & $1.80 \mathrm{E}-06$ & $\mathbf{0}$ & 0.331 & 11.832 & $\mathbf{0}$ \\
\hline & Average WGI & 1.544 & 0.203 & 0.274 & 7.607 & $\mathbf{0}$ \\
\hline
\end{tabular}

The adjusted $\mathrm{R}^{2}$ for $\mathrm{S} \& \mathrm{P}$ model is 0.802 . This measures the variation in SCRs that is explained by the identified explanatory variables. It, suggests that $80.2 \%$ of SCRs of S\&P is explained by the identified explanatory variables. In other words, $19.8 \%$ of SCRs cannot be explained by the identified explanatory variables. However, adjusted $\mathrm{R}^{2}$ of 0.802 denote that the regression model has a good fit. Also, the significance of the overall model is measured by the F-test statistic. The p-value (Sig.) of the F statistics $(0.000)$ signify that the model is statistically significant at $1 \%$. Consequently, the evidence against $\mathrm{H}_{O}$ is strong. So, we reject the $\mathrm{H}_{O}$ and conclude that S\&P model does predict the outcome better than just chance.

Furthermore, the significance of each explanatory variable is also examined, in order to establish their relationship with SCRs. Although GDP growth rate and current account balance have a positive sign with SCRs as expected, they are not statistically significant at either $10 \%, 5 \%$ or $1 \%$. Their p-values of 0.806 and 0.564 respectively, denotes that there is no evidence against $\mathrm{H}_{\mathrm{O}}$. Therefore, we accept the null hypothesis and conclude that there is no relationship between SCRs and either GDP growth rate or current account balance. However, a negative relationship was observed between inflation and SCRs. This implies that increase in inflation will lead to decrease in SCRs. Inflation is statistically significant at $1 \%$ significance level with a p-value of 0.000 . Invariably, the $\mathrm{H}_{\mathrm{O}}$ will be rejected. Also, inflation has a coefficient of -0.112 . This indicates that 1 unit increase in inflation rate will lead to decrease in SCRs by 0.112 notches and vice versa, holding all other variables constant. Similarly, a negative relationship is observed between government debt and SCRs, which is also significant at $1 \%$ with a p-value of 0.000 . Government debt has a coefficient of -0.033 , which denote that 1 unit increase in government debt rate will lead to 0.033 notches decrease in SCRs and vice versa, holding all other variables constant.

GDP per capital is positively significant with SCRs at a significance level of $1 \%$. Its p-value of 0.000 , result in the rejection of HO. Hence, a positive relationship was observed. Also, its coefficient of 4.627E-05 indicates that 1 unit increase in GDP per capital will lead to 4.627E-05 notches increase in SCRs and vice versa, holding all other variables constant. In the same way, reserves and average WGI has a positive relationship with SCRs at $1 \%$ significance level. They both have a p-value of 0.000 , which denotes that the $\mathrm{HO}$ will be rejected. In addition, the coefficient of reserves is 1.795E-06, while that of average WGI is 1.544. This suggests that 1 unit increase in reserves/average WGI will lead to 1.795E-06/1.544 notches increase in SCRs and vice versa, holding all other variables constant. Conversely, external debt stocks have a negative relationship with SCRs with a p-value of 0.000 . This means that external debt is statistically significant at $1 \%$ significance level. So, the HO is rejected. Moreover, the coefficient of external debt is -0.013 . This indicates that 1 unit increase in external debt will lead to 0.013 notches decrease in SCRs and vice versa, holding all other variables constant. 
In general, Inflation, Government debt, GDP per capita, External debt stocks, Reserves, and Average WGI are statistically significant in S\&P's model. Table 10 presents the synopsis of all the explanatory variables employed in the model.

Table 10. S\&P Hypothesis Testing (Author generated)

\begin{tabular}{|l|c|c|c|}
\hline $\begin{array}{l}\text { Explanatory } \\
\text { Variables }\end{array}$ & Relationship & P-Values & Decision \\
\hline $\begin{array}{l}\text { GDP growth } \\
\text { rate }\end{array}$ & + & 0.806 & Accept the $\mathrm{H}_{\mathrm{O}}$ \\
\hline $\begin{array}{l}\text { Inflation } \\
\begin{array}{l}\text { Government } \\
\text { debt }\end{array}\end{array}$ & - & 0 & Reject the $\mathrm{H}_{\mathrm{O}}$ \\
\hline $\begin{array}{l}\text { Current } \\
\text { account } \\
\text { balance }\end{array}$ & + & 0.564 & Reject the $\mathrm{H}_{\mathrm{O}}$ \\
\hline GDP per capita & + & 0 & Accept the $\mathrm{H}_{\mathrm{O}}$ \\
\hline $\begin{array}{l}\text { External debt } \\
\text { stocks }\end{array}$ & - & 0 & Reject the $\mathrm{H}_{\mathrm{O}}$ \\
\hline Reserves & + & 0 & Reject the $\mathrm{H}_{\mathrm{O}}$ \\
\hline Average WGI & + & 0 & Reject the $\mathrm{H}_{\mathrm{O}}$ \\
\hline
\end{tabular}

\subsubsection{Moody's Regression Result}

The model has a good explanatory power has measured by the adjusted R2 of 0.741 . This suggests that $74.1 \%$ variation in Moody's SCRs is explained by the identified explanatory variables. In other words, $25.9 \%$ of the model is explained by other explanatory variables which are not included in the model. Hence, the model has a good fit. Also, the p-value (0.000) of the F-statistics denote that the overall model is statistically significant at a significance level of $1 \%$. Therefore, $\mathrm{HO}$ is rejected with the conclusion that Moody's model does predict the outcome better than just chance. The regression result of Moody's is presented in table 11.

Table 11. Moody's regression result (SPSS)

\begin{tabular}{|l|c|c|c|c|c|}
\hline \multicolumn{7}{|c|}{ Model Summary } \\
\hline Model & $\mathrm{R}$ & $\mathrm{R}$ Square & $\begin{array}{c}\text { Adjusted } \\
\text { R Square }\end{array}$ & $\begin{array}{c}\text { Std. Error } \\
\text { of the Estimate }\end{array}$ & $\begin{array}{c}\text { Durbin- } \\
\text { Watson }\end{array}$ \\
\hline 1 & $.865 \mathrm{a}$ & 0.748 & 0.741 & 1.5277 & 0.433 \\
\hline $\begin{array}{l}\text { a. Predictors: (Constant), Average WGI, Current account balance, Government debt, Inflation, } \\
\text { Reserves, GDP growth rate, External debt stocks, GDP per capita }\end{array}$ \\
\hline
\end{tabular}

\begin{tabular}{|l|l|c|c|c|c|c|}
\hline \multicolumn{2}{|l|}{ Model } & Sum of Squares & Df & Mean Square & F & Sig. \\
\hline \multirow{3}{*}{1} & Regression & 2013.327 & 8 & 251.666 & 107.832 & $.000 \mathrm{~b}$ \\
\cline { 2 - 7 } & Residual & 679.153 & 291 & 2.334 & & \\
\cline { 2 - 7 } & Total & 2692.48 & 299 & & & \\
\hline
\end{tabular}




\begin{tabular}{|c|c|c|c|c|c|c|}
\hline \multicolumn{7}{|c|}{ Coefficientsa } \\
\hline \multirow[t]{2}{*}{ Model } & & \multicolumn{2}{|c|}{ Unstandardized Coefficients } & \multirow{2}{*}{$\begin{array}{c}\begin{array}{c}\text { Standardized } \\
\text { Coefficients }\end{array} \\
\text { Beta }\end{array}$} & \multirow[t]{2}{*}{$\mathrm{T}$} & \multirow{2}{*}{ Sig. } \\
\hline & & $\mathrm{B}$ & Std. Error & & & \\
\hline \multirow{9}{*}{1} & (Constant) & 15.34 & 0.324 & & 47.275 & 0 \\
\hline & \begin{tabular}{|l} 
GDP \\
rate
\end{tabular} & -0.024 & 0.027 & -0.03 & -0.915 & 0.361 \\
\hline & Inflation & -0.09 & 0.017 & -0.169 & -5.456 & 0 \\
\hline & $\begin{array}{l}\text { Government } \\
\text { debt }\end{array}$ & -0.03 & 0.005 & -0.201 & -6.567 & 0 \\
\hline & $\begin{array}{l}\text { Current } \\
\text { account } \\
\text { balance }\end{array}$ & -0.022 & 0.019 & -0.049 & -1.159 & 0.247 \\
\hline & GDP per capita & 5.23E-05 & 0 & 0.244 & 5.342 & 0 \\
\hline & $\begin{array}{|ll|}\begin{array}{l}\text { External debt } \\
\text { stocks }\end{array} & \\
\end{array}$ & -0.016 & 0.002 & -0.367 & -9.48 & 0 \\
\hline & Reserves & $1.89 \mathrm{E}-06$ & 0 & 0.328 & 10.247 & 0 \\
\hline & Average WGI & 1.642 & 0.246 & 0.275 & 6.673 & 0 \\
\hline
\end{tabular}

Although GDP growth rate and current account balance have a negative coefficient which is quite surprising, they are statistically insignificant. Their p-value of 0.361 (GDP growth rate) and 0.247 (current account balance) are not significant at either $1 \%, 5 \%$, or $10 \%$ significance level. This suggests that they have no relationship with Moody's SCRs and so, the HO will be accepted. Furthermore, inflation, government debt, and external debt demonstrate a negative relationship with Moody's SCRs. They are all statistically significant at $1 \%$ significance level with a p-value of 0.000 , which denote that the $\mathrm{HO}$ will be rejected. Inflation has a coefficient of -0.090 . This denotes that for every 1 unit increase in inflation rate, SCRs will reduce by 0.090 notches and vice versa, holding all other variables constant. Similarly, the coefficient of government debt (-0.030) and external debt $(-0.016)$ indicate that for every 1 unit increase in these variables, SCRs will decrease by 0.030 and 0.016 notches respectively and vice versa, holding all other variables constant.

Also, GDP per capita, reserves, and average WGI are statistically significant at $1 \%$ significance level with a p-value of 0.000 . They all have a positive relationship with SCRs which result into the rejection of the HO. GDP per capita has a coefficient of 5.230E-05, while the reserve is with the coefficient of $1.885 \mathrm{E}-06$. Therefore, a 1 unit increase in these variables will increase SCRs by 5.230E-05/1.885E-06 notches respectively and vice versa, holding all other variables constant. Meanwhile, the coefficient of average WGI (1.642) indicates that for every 1 unit increase, SCRs will increase by 1.642 notches and vice versa, holding all other variables constant. Generally, Inflation, Government debt, GDP per capita, External debt stocks, Reserves, and Average WGI are statistically significant in Moody's model. The summary of all the explanatory variables employed in the model is presented in table 12.

Table 12. Moody's hypothesis testing (Author generated)

\begin{tabular}{|l|c|c|l|}
\hline $\begin{array}{l}\text { Explanatory } \\
\text { Variables }\end{array}$ & Relationship & P-Values & Decision \\
\hline GDP growth rate & - & 0.361 & Accept the $\mathrm{H}_{\mathrm{O}}$ \\
\hline Inflation & - & 0 & Reject the $\mathrm{H}_{\mathrm{O}}$ \\
\hline Government debt & - & 0 & Reject the $\mathrm{H}_{\mathrm{O}}$ \\
\hline $\begin{array}{l}\text { Current account } \\
\text { balance }\end{array}$ & - & 0.247 & Accept the $\mathrm{H}_{\mathrm{O}}$ \\
\hline GDP per capita & + & 0 & Reject the $\mathrm{H}_{\mathrm{O}}$ \\
\hline External debt stocks & - & 0 & Reject the $\mathrm{H}_{\mathrm{O}}$ \\
\hline Reserves & + & 0 & Reject the $\mathrm{H}_{\mathrm{O}}$ \\
\hline Average WGI & + & 0 & Reject the $\mathrm{H}_{\mathrm{O}}$ \\
\hline
\end{tabular}




\subsection{Comparison between S\&P's Model and Moody's SCRs.}

The explanatory power of the two models is quite high, which denote that they have a good fit. However, S\&P's model measures higher variation in SCRs than Moody's model. The adjusted $\mathrm{R}^{2}$ of S\&P (0.802) and Moody (0.741) indicate that S\&P model has 6\% higher explanatory power than Moody's model. This suggests that the weight the CRAs attributes to each identified variable differs. However, this is not surprising, has it is consistent with IMF (2010) assertion. Also, both models are statistically significant at $1 \%$ significance level with the p-value of 0.000 , as measured by the F-statistics. Hence, all the identified variables taken together has a linear relationship with the two models SCRs.

Regarding the individual explanatory variables, GDP growth rate and current account balance have an opposite sign in both models. While GDP growth rate and current account balance have a positive sign in S\&P model, it was a negative sign in Moody's model. However, these variables are not statistically significant in both models. Hence, no relationship was found. Also, inflation, government debt, and external debt have a negative relationship with SCRs in the two models and were all statistically significant at $1 \%$ significance level. However, assigning of different weight by CRAs makes their impact on SCRs differs. A 1 unit increase in inflation rate will decrease S\&P SCRs by -0.112 notches whereas Moody's SCRs will be decreased by -0.090 notches and vice versa. Similarly, for every 1 unit increase in government debt, S\&P and Moody SCRs will decrease by -0.033 and -0.030 notches respectively. Also, a 1 unit increase in external debt will decrease S\&P SCRs by -0.013 notches whereas Moody's SCRs will be decreased by -0.016 notches and vice versa. This suggests that S\&P assign a higher weight to inflation and government debt, whereas Moody assigns a higher weight to external debt.

Also, GDP per capita, reserves, and average WGI are positively related with the two model SCRs. Their p-value of 0.000 denotes that they are all significant at $1 \%$ significance level. Furthermore, the impact of these variables on the two models also differs. A 1 unit increase in GDP per capita will increase S\&P SCRs by 4.627E-05 notches whereas, Moody SCRs will be increased by 5.230E-05 notches and vice versa. Also, a 1 unit increase in reserves and average WGI will increase S\&P SCRs by $1.795 \mathrm{E}-06$ and 1.544 notches respectively, whereas, Moody SCRs will be increased by $1.885 \mathrm{E}-06$ and 1.642 notches respectively and vice versa. This suggests that Moody's SCRs assign more weight to these variables, as compared to S\&P's SCRs. In general, the same explanatory variables were found to be significant in both models with the same relationship (signs). However, the identified explanatory variables could not explain 19.8\% variation in S\&P SCRs and 25.9\% in Moody SCRs. This implies that these variations are accounted for by others variables which are not included in the models.

\subsection{Macroeconomic Variables}

In identifying the determinants of the sovereign credit rating of the emerging markets, seven macroeconomic variables were examined, using S\&P and Moody ratings. Two of the variables have no relationship with the SCRs issued to the emerging markets. Furthermore, five variables are found to be an essential determinant of emerging markets SCRs. While two of the variables are found to have a positive relationship with SCRs, the other three are negatively related to SCRs. These variables are:

\subsubsection{The GDP Growth Rate}

The GDP growth was expected to have a positive relationship with SCRs. This is because it measures the growth of an economy, which gives an indicator of how easily a country can pay its debt. However, no relationship was found in both ratings issued by S\&P and Moody. The lack of relationship between SCRs and GDP growth could be because many emerging markets tend to grow faster than the developed countries. This is consistent with Erdem and Varli (2014) findings, though their study was based on S\&P ratings only.

\subsubsection{Current Account Balance}

Current account balance was expected to have a positive relationship with SCRs. This is because high current account balance can indicate an increase in a country's net foreign asset, which can lead to growth and invariably improve the sustainability of the country. However, no relationship was found. This is consistent with the findings of Archer et al. (2007), which revealed that there is no relationship between either Fitch's or Moody's, or S\&P's rating and current account balance. On the other hand, Afonso et al. (2011) reported that current account balance has a negative impact on rating and was found to be significant.

\subsubsection{GDP Per Capita}

As expected, the GDP per capita has a positive relationship with SCRs of both S\&P and Moody. This indicates that a country with high GDP per capita tends to have high SCRs. An explanation for this is that the GDP per capita is used to measure the economic performance of a country. Therefore, an economy that is more enhanced, is likely to have a more stable debt structures. This reflects the debt repayment ability of a country and hence, it 
is associated with a higher rating.

\subsubsection{Reserves}

Reserves have a positive relationship with SCRs of both S\&P and Moody. This is expected because it measures the liquidity of a country, which indicates its ability in honouring its foreign currency obligations. Therefore, a country with high reserves tends to have a low default risk and thus, rated high. This is consistent with all the findings in the previous literature and so, it emphasises the importance of reserves in determining the rating of a country. Montes et al. (2016) asserted that foreign reserve is significant and positive across all the CRAs. Hence, the reserve has a positive impact in determining the SCRs of an emerging market.

\subsubsection{Inflation Rate}

This is not surprising, as inflation is expected to have a negative relationship with SCRs. This is because high inflation reduces the purchasing power of a currency and also depicts that there is an economic instability. Therefore, a country with a high inflation rate tends to have a high probability of default risk and hence, rated low. This is consistent with most of the findings in the previous literature (i.e. Afonso et al., 2007; Archer et al., 2007; Montes et al., 2016).

\subsubsection{Government Debt}

Government debt is negatively related to SCRs of both S\&P and Moody. This is expected; as high government debt is associated with high default risk. This is because high-interest rate would be required in order to service the debt. This is consistent with Afonso et.al (2007), and Afonso et.al (2011) findings. Their study observed a negative relationship between government debt and the SCRs of the three major CRAs. This suggests that a country with high government debt tend to have a low SCRs.

\subsubsection{External Debt}

External debt also has a negative relationship with SCRs. The higher the external debt of a country, the greater the risk of default. Therefore, a country with a low external debt tends to have a low risk of default and thus, rated high. This in line with previous findings. Cantor and Packer (1996) asserted that lower external debt is correlated with higher ratings. Also, Rowland (2004), Afonso et.al (2011), Biglaiser and Staats (2012), Erdem and Varli (2014), and Montes et al. (2016), all argued that external debt seems to be an essential determinant of ratings.

\subsection{Controversy in the Study}

The controversy in the study has regarded the inclusion or exclusion of qualitative/political variables in determining the SCRs is also examined. In order to identify the relationship between SCRs and qualitative/political variables, the study employed the average of six world governance indicators. These are Government Effectiveness, Rule of Law, Control of Corruption, Regulatory Quality, Political Stability and Absence of Violence/Terrorism, Voice and Accountability. As expected, a positive relationship was found between the average of world governance indicators and SCRs of S\&P and Moody. This is because governance indicators reflect the willingness of the government to service its debt. This is consistent Erdem and Varli (2014) assertion. Their study also employed the average of the six world governance indicators with the use of S\&P rating. They observed that governance indicators have a positive impact on SCRs. However, several qualitative/political variables have been explored in analysing the relationship between rating and qualitative variables.

Furthermore, Montes et al. (2016) argued that institutional dimension (i.e. law and order, and democratic) were negatively significant, which means that increase in these variables can lead to economic stability, which as a result can improve SCRs of a country. Also, their study revealed that corruption was significant and negative. This suggests that increase in corruption would lead to decrease in SCRs. In contrast, some scholars argued that there should be no inclusion of qualitative/political variables. Cantor and Packer (1996), Afonso (2003), Alex (2003), and Rowland (2004) are with the perception that economic variables are the factors behind SCRs. Although their study did not examine any qualitative/political variable, they argued that macroeconomic variables are sufficient enough to determine the SCR of a country.

In general, considering the facts that CRAs assert that they put into consideration some qualitative/political variables in determining the rating of an issuer, makes it even more important for the emerging markets to improve on their political factors in order to enhance their ratings. Also, the qualitative/political variables examined in this study showed that governance indicators have a positive impact on rating, which is also in line with some previous findings. Therefore, the authors are of the opinion that qualitative/political variables are one 
of the determinants of SCRs of the emerging markets. So, improvement in qualitative/political variables of a country will result in higher sovereign credit rating.

\section{Conclusion, Limitations and Recommendations}

\subsection{Conclusion}

Markets globalization and financial integration have tremendously increased the demand of SCR in recent years, especially the emerging market. This is mainly because SCR strongly influences the flow of capital to emerging markets. However, some emerging markets had faced debt crises in recent years which have drawn the attention of many in considering and questioning the CRAs and their rating system. Even though, the methodologies used by the CRAs and the weight assigned to various variables are not disclosed to the public, the effects of several variables on ratings can be predicted with the use of econometric models. This study critically investigates the determinant of SCRs in the emerging markets, during 2001 to 2015. This was conducted in 20 emerging markets, using S\&P and Moody ratings. As regards the methodological approach, the study adopts a linear framework. In particular, pooled OLS regression method is used in identifying the essential determinant of SCRs. The explanatory power of the estimated models have a good performance across both CRAs. The same results are discovered in both S\&P and Moody model. All the significant variables in S\&P are also found significant in Moody with the same signs. However, the study examined seven macroeconomic variables, of which two of the variables have no relationship with the SCRs issued to the emerging markets. Furthermore, five variables are found to be an essential determinant of emerging markets SCRs. Two of the variables are found to have a positive relationship with SCRs, and the other three are negatively related to SCRs. The study showed that GDP per capital and reserves has a positive impact on SCRs whereas, inflation, government debt, and external debt have a negative impact on the rating. On the contrary, no systemic relationship was found between SCRs and either GDP growth rate or current account balance. These two variables were insignificant in both model with the opposite signs.

\subsection{Limitations}

Having addressed the aim and objectives of the study, some limitations are faced with the study of this nature. Firstly, is the unavailability of data. Some samples of the emerging markets would have been considered in this study, but their data were not available. Similarly, the study intended to use the ratings issued by the three major CRAs (i.e. S\&P, Moody, and Fitch) for comparison purpose, but the author could not have access to the historical rating issued by Fitch. Besides, the time horizon adopted in the study for the period of 2001 to 2015 , also poses some restrictions to the samples examined. This is because some emerging markets have just been rated in recent years and their data are not complete for the study duration.

The methodology and data type adopted also poses a significant limitation in the comparison of the study findings. There are two major strands of an econometric model in the literature, of which the pooled OLS regression method adopted in the study is just a sub-part of one. Also, some of the previous literature used a cross-section data as opposing the panel data adopted in this study. However, the methodology adopted and data type was also used in some of the previous studies. Lastly, is the time constraints. The investigation was carried out within a short duration of 4months which restricted the author in examining some variables and some aspect of SCR determinant. For instance, the author would have loved to analyse the predictive power of the identified explanatory variables but time could not permit.

\subsection{Recommendation}

The first recommendation will be to replicate the study to be able to analyse the predictive power of the identified explanatory variables. This is to know how strong the estimated models can predict the SCRs of an emerging market. Also, recent years can be used (let say from 2011) to give an opportunity for some emerging markets to be examined. In addition, there are very few previous studies that examined the cross-section data of emerging markets. In fact, the authors could only cite one (i.e. Rowland, 2004). This can be looked into also, using recent year.

Furthermore, the two strand of econometric approach in the literature can be examined together like some previous studies did (such as Afonso et al. 2007, 2011, Erderm and Varli, 2014), this will enable easy comparison among studies. Lastly, research can be carried out based on regions (i.e. market classification). This is to investigate whether the CRAs are biased in their assessment when issuing SCR to emerging market on a regional basis. 


\section{References}

Afonso, A. (2003). Understanding the determinants of sovereign debt ratings: Evidence for the two leading agencies. Journal of Economics and Finance, 27(1), 56-74. https://doi.org/10.1007/BF02751590

Afonso, A., Gomes, P. M., \& Rother, P. (2007). What' Hides' Behind Sovereign Debt Ratings?

Afonso, A., Gomes, P. M., \& Rother, P. (2011). Short-and long-run determinants of sovereign debt credit ratings. International Journal of Finance \& Economics, 16(1), 1-15. https://doi.org/10.1002/ijfe.416

Alexe, S., Hammer, P. L., Kogan, A., \& Lejeune, M. A. (2003). A non-recursive regression model for country risk rating. RUTCOR-Rutgers University Research Report RRR, 9, 1-40

Al-Sakka, R., \& ap Gwilym, O. (2009). Heterogeneity of sovereign rating migrations in emerging countries. Emerging Markets Review, 10(2), 151-165. https://doi.org/10.1016/j.ememar.2008.12.001

Alsakka, R., \& ap Gwilym, O. (2012). Rating agencies' credit signals: An analysis of sovereign watch and outlook. International Review of Financial Analysis, 21, 45-55. https://doi.org/10.1016/j.irfa.2011.10.002

Altenkirch, C. (2005). The determinants of sovereign credit ratings: a new empirical approach. South African Journal of Economics, 73(3), 462-473. https://doi.org/10.1111/j.1813-6982.2005.00031.x

Archer, C. C., Biglaiser, G., \& DeRouen, K. (2007). Sovereign bonds and the "democratic advantage": Does regime type affect credit rating agency ratings in the developing world?. International Organization, 61(2), 341-365. https://doi.org/10.1017/S0020818307070129

Banerjee, A. (2006). Behind the boom in emerging market equity investing. Standard and Poor's, August.

Bennell, J. A., Crabbe, D., Thomas, S., \& Ap Gwilym, O. (2006). Modelling sovereign credit ratings: Neural networks versus ordered probit. Expert Systems with Applications, 30(3), 415-425. https://doi.org/10.1016/j.eswa.2005.10.002

Biglaiser, G., \& Staats, J. L. (2012). Finding the "democratic advantage" in sovereign bond ratings: the importance of strong courts, property rights protection, and the rule of law. International Organization, 66(3), 515-535. https://doi.org/10.1017/S0020818312000185

Biglaiser, G., Hicks, B., \& Huggins, C. (2008). Sovereign bond ratings and the democratic advantage: portfolio investment in the developing world. Comparative Political Studies, 41(8), 1092-1116. https://doi.org/10.1177/0010414007308021

Bissoondoyal-Bheenick, E. (2005). An analysis of the determinants of sovereign ratings. Global Finance Journal, 15(3), 251-280. https://doi.org/10.1016/j.gfj.2004.03.004

Cantor, R., \& Packer, F. (1996). Determinants and impact of sovereign credit ratings. Economic policy review, 2(2). https://doi.org/10.1111/j.1468-036X.1996.tb00040.x

Cantor, R., Emery, K., Duggar, E., \& Cailleteau, P. (2008). Sovereign Default and Recovery Rates, 1983-2007. New York: Moody's Investors Service, Inc.

Colquitt, J. (2007). Credit risk management: How to avoid lending disasters and maximize earnings. McGraw Hill Professional.

Dailami, M., \& Hauswald, R. (2003). The emerging project bond market: Covenant provisions and credit spreads. The World Bank. https://doi.org/10.1596/1813-9450-3095

De Haan, J., \& Amtenbrink, F. (2011). Credit rating agencies. De Nederlandsche Bank Working Paper No. 278. https://doi.org/10.2139/ssrn.1950563

Dittmar, R. F., \& Yuan, K. (2008). Do sovereign bonds benefit corporate bonds in emerging markets?. The Review of Financial Studies, 21(5), 1983-2014. https://doi.org/10.1093/rfs/hhn015

Eliasson, A. C. (2002). Sovereign credit ratings (No. 02-1). Research Notes. Deutsche Bank Research.

Erb, C. B., Harvey, C. R., \& Viskanta, T. E. (2000). Understanding emerging market bonds. Emerging Markets Quarterly, 4, 7-24.

Erdem, O., \& Varli, Y. (2014). Understanding the sovereign credit ratings of emerging markets. Emerging Markets Review, 20, 42-57. https://doi.org/10.1016/j.ememar.2014.05.004

Gonis, E., Paul, S., \& Tucker, J. (2012). Rating or no rating? That is the question: an empirical examination of UK companies. The European Journal of Finance, 18(8), 709-735. https://doi.org/10.1080/1351847X.2011.649215 
Hill, P., Brooks, R., \& Faff, R. (2010). Variations in sovereign credit quality assessments across rating agencies. Journal of Banking \& Finance, 34(6), 1327-1343. https://doi.org/10.1016/j.jbankfin.2009.11.028

Host, A., Cvečić, I., \& Zaninović, V. (2012). Credit rating agencies and their impact on spreading the financial crisis on the eurozone. Ekonomska misao i praksa, (2), 639-662.

Kim, S. J., \& Wu, E. (2008). Sovereign credit ratings, capital flows and financial sector development in emerging markets. Emerging markets review, 9(1), 17-39. https://doi.org/10.1016/j.ememar.2007.06.001

Kronwald, C. (2009). Credit rating and the impact on capital structure. Who knows what: Information on capital markets. University of Hohenheim.

Montes, G. C., de Oliveira, D. S., \& de Mendonça, H. F. (2016). Sovereign credit ratings in developing economies: New empirical assessment. International Journal of Finance \& Economics, 21(4), 382-397. https://doi.org/10.1002/ijfe.1551

MOODY'S INVESTORS SERVICE (2006). Moody's ratings system: In brief. [online] Available from: https://www.moodys.com/uploadpage/2005700000433096

Mulder, M. C. B., \& Monfort, B. (2000). Using credit ratings for capital requirementson lending to emerging market economies: Possible impact of a new basel accord (No. 0-69). International Monetary Fund. https://doi.org/10.5089/9781451849059.001

Ozturk, H. (2014). The origin of bias in sovereign credit ratings: Reconciling agency views with institutional quality. The Journal of Developing Areas, 161-188. https://doi.org/10.1353/jda.2014.0066

Pavkovic, A., \& Vedriš, D. (2011). Redefined role of credit rating agencies in contemporary financial systems. Ekonomska misao i praksa: časopis Sveučilista u Dubrovniku, 20(1), 225.

Reinhart, C. M. (2002). Default, currency crises, and sovereign credit ratings. the world bank economic review, 16(2), 151-170. https://doi.org/10.1093/wber/16.2.151

Reinhart, C. M., \& Rogoff, K. S. (2004). Serial default and the" paradox" of rich-to-poor capital flows. American Economic Review, 94(2), 53-58. https://doi.org/10.1257/0002828041302370

Reisen, H., Von Maltzan, J., \& Larraín, G. (1998). Emerging market risk and sovereign credit ratings. En: X Seminario Regional de Política Fiscal: compendio de documentos-Santiago: CEPAL, 1998-p. D1-D21.

Rowland, P. (2004). Determinants of spread, credit ratings and creditworthiness for emerging market sovereign debt: a follow-up study using pooled data analysis. Borradores de Economía; No. 296.

Shen, C. H., Huang, Y. L., \& Hasan, I. (2012). Asymmetric benchmarking in bank credit rating. Journal of International Financial Markets, Institutions and Money, 22(1), 171-193. https://doi.org/10.1016/j.intfin.2011.08.004

Standard \& Poor's Financial Services, (2014). . Ratings direct: Standard \& Poor's ratings definitions. [online] Available from:

https://www.spratings.com/documents/20184/86966/Standard+\%26+Poor\%27s+Ratings+Definitions/fd2a2 a96-be56-47b8-9ad2-390f3878d6c6

White, L. J. (2010). Markets: The credit rating agencies. Journal of Economic Perspectives, 24(2), 211-226. https://doi.org/10.1257/jep.24.2.211

Zheng, L. (2012). Are sovereign credit ratings objective? A tale of two agencies. Journal of Applied Finance and Banking, 2(5), 43.

\section{Copyrights}

Copyright for this article is retained by the author(s), with first publication rights granted to the journal.

This is an open-access article distributed under the terms and conditions of the Creative Commons Attribution license (http://creativecommons.org/licenses/by/4.0/). 